\title{
Linking C\&I to a Code of Practice for Industrial Tropical Tree Plantations
}

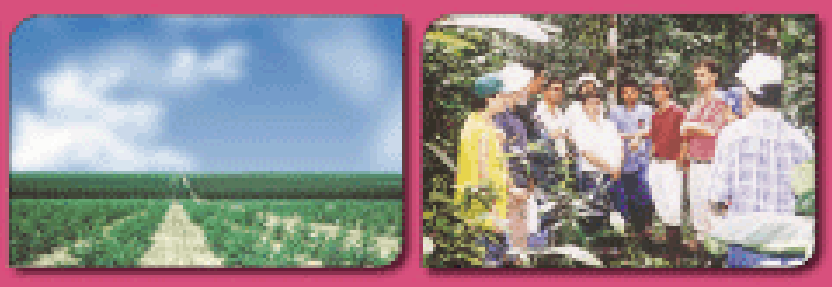

John Poulsen, Grahame Applegate and Dan Raymond 
(C) 2001 by Center for International Forestry Research All rights reserved. Published in 2001

Printed by SMK Grafika Desa Putera, Indonesia

Cover photos by Christian Cossalter, John Poulsen, Cesar Sabogal

\section{ISBN 979-8764-65-X}

\section{Published by}

Center for International Forestry Research

Bogor, Indonesia

P.O. Box 6596 JKPWB, Jakarta 10065, Indonesia

Tel.: +62 (251) 622622; Fax: +62 (251) 622100

E-mail: cifor@cgiar.org

Web site: http://www.cifor.cgiar.org 


\section{C\&I for Sustainable Development of Industrial Tropical Tree Plantations (with links to a Code of Practice)}
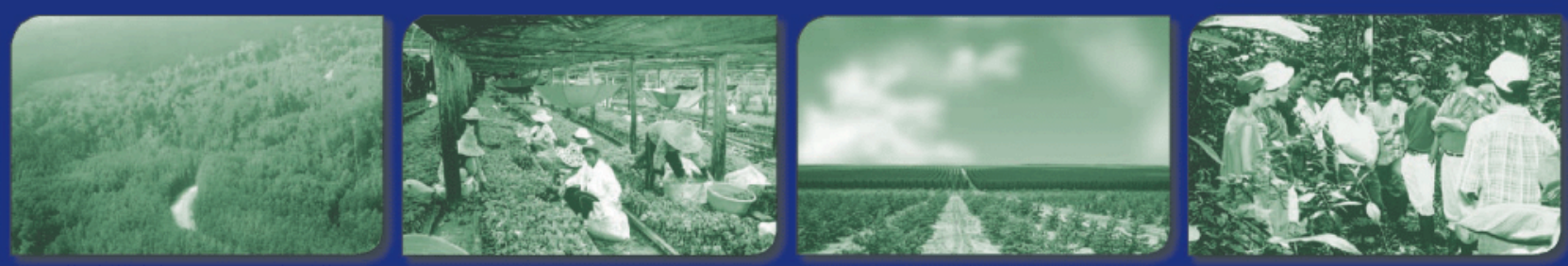

John Poulsen and Grahame Applegate 


\title{
C\&I for Sustainable Development of Industrial Tropical Tree Plantations (with links to a Code of Practice)
}

\author{
John Poulsen
}

Grahame Applegate

As part of the continuing search for practical ways to apply C\&I to development, this document is offered to directly provide a link between C\&I and a code of practice for sustainable development of largescale tropical industrial plantations. Adoption of C\&I requires consultation but must be based on practice - this book offers a framework for field testing the results of which should inform progressive improvement of both the criteria and the codes of practice. For this reason, CIFOR invites all users of this text to provide feedback, including suggestions for improvement, using the following addresses:

John Poulsen:

$<$ j.poulsen@cgiar.org>

Fax: (62-251) 622100

Grahame Applegate:

<g.applegate@cgiar.org> Fax: (62-251) 622100 


\section{Table of Contents}

Acknowledgements $\quad$ iv

Foreword v v

1. Introduction 1

1.1. The Problem 1

1.2. The Purpose 2

1.3. Why Criteria and Indicators?

1.4. Why a Code of Practice? 3

1.5. Why Linking the Development of C\&I with Developing a Code of Practice? 4

2. Approach 5

3. Results and Discussion 6

3.1. C\&I for Social and Community Relationship Issues at Landscape Level 6

3.2. C\&I for Production Planning and Management Issues at Stand and Landscape Level

3.3. Environmental Issues at Landscape Level $\quad 7$

4. C\&I for Plantations 8

5. Conclusions and Recommendations $\quad 25$

6. References Cited 27

7. Further Reading $\quad 30$ 


\section{List of Tables}

Table 1. The revised set of Criteria and Indicators for Sustainable Management of Large-Scale Timber Plantations. The last entry in the verifier column referred to by section number relates to the Code of Practice for Industrial Tree Plantation Development in the Tropics.

Table 2a. The revised set of Criteria and Indicators for Sustainable Management of Large-Scale Timber Plantations. The last entry in the verifier column referred to by section number relates to the Code of Practice for Industrial Tree Plantation Development in the Tropics. Cf. Annex 2, and Table 2b and $2 \mathrm{c}$.

Table $2 \mathrm{~b}$. The revised set of Criteria and Indicators for Sustainable Management of Large-Scale Timber Plantations. The last entry in the verifier column referred to by section number relates to the Code of Practice for Industrial Tree Plantation Development in the Tropics. Cf. Annex 2, and Table 2a and $2 \mathrm{c}$.

Table 2c. The revised set of Criteria and Indicators for Sustainable Management of Large-Scale Timber Plantations. The last entry in the verifier column referred to by section number relates to the Code of Practice for Industrial Tree Plantation Development in the Tropics. Cf. Annex 2, and Table 2a and $2 \mathrm{~b}$.

Table 3. The revised set of Criteria and Indicators for Sustainable Management of Large-Scale Timber Plantations. The last entry in the verifier column referred to by section number relates to the Code of Practice for Industrial Tree Plantation Development in the Tropics. Cf. Annex 3. 


\section{List of Annexes}

ANNEX 1. The initial set of Social Criteria and Indicators, which were evaluated and used as the basis for the workshop and the development of the C\&I (cf. Table 1 for the revised set).

ANNEX 2. The initial set of Management Criteria and Indicators, which were evaluated and used as the basis for the workshop (cf. Table $2 a, 2 b$ and $2 c$ for the revised set).

ANNEX 3. The initial set of Ecological Criteria and Indicators, which were evaluated and used as the basis for the workshop (cf. Table 3 for the revised set). 


\section{Acknowledgements}

The contributions of the following organisations and individuals are gratefully acknowledged:

- $\quad$ APRIL Group for funding support and hosting a workshop in Sumatra.

- $\quad$ LEI, LATIN and IPB for providing professional expertise.

- URS Forestry for consulting services.

- Melinda Wan for typing the report.

- Levania Santoso for editorial assistance. 


\section{Foreword}

Over the last ten years there has been an increasing emphasis on development of plantation estates for both wood fiber and agricultural crops such as oil palm. While the end products may be different, the principles necessary for the sustainable development and establishment of industrial plantations to account for the social, environmental and biodiversity aspects are the same.

A general, and frequently raised, concern is that the development of criteria and indicators $(C \& I)$, and associated verifiers, for sustainable management of natural forests, do not sufficiently consider the practicality and relevance to forest managers. Hence it can be argued that the adoption of these criteria and indicators has been limited.

The efforts to develop criteria and indicators for sustainable management of tropical plantations is in its infancy. As their preparation are in the early stages of the development, it provides an opportunity to investigate a different approach compared to that used for the development of C\&I for natural forest management (the latter including previous work by CIFOR).

This document has been prepared by the Center for International Forestry Research (CIFOR). This is the first attempt to develop a process designed to link the development of C\&I more closely with practical and sustainable plantation development principles and practices, the latter expressed through a Code of Practice. To ensure that the two systems are mutually compatible they have been developed simultaneously. The process aims to ensure that the standards for practical development of industrial plantations reflect, properly and appropriately, the needs and concerns expressed in the criteria and indicators for sustainable management and development of planted forests. This is intended to both increase the relevance and hence perhaps the adoption of C\&I, such as those developed by CIFOR.

Criteria and indicators can provide the benchmark for a plantation owner (small holders or large holders) to assess progress towards sustainable forest management within their forest 
estate. Criteria and indicators can be used as a means of assessing compliance with a suitable set of benchmarks such as contained within a Code of Practice for Industrial Tree Plantation Development in the Tropics (Code).

The Code provides details on principles relating to improved plantation development. The acceptance and adoption of the Code also serves as an expression of the plantation owners' commitment to sustainable forest management.

The ability of the countries in Asia to implement sustainable forest management will be enhanced through the application of this document and process, whereby compliance by appropriate criteria and indicators for plantation development and management can be adhered to following appropriate practices, as stipulated in the Code.

Since this is the first attempt at linking C\&I with codes of practice, we would therefore be particularly grateful for comments on the usefulness of this approach. This will aid us in directing future efforts.

\section{Box 1. Terminology}

A principle is defined as fundamental truth or law as the basis of reasoning or action. In the context of sustainable forest management, a principle is viewed as the primary framework for managing forests in a sustainable fashion. It provides the justification for criteria, indicators and verifiers.

Consider that principle embodies human wisdom. Liang (1994) defines wisdom as a small increment in knowledge created by a person's (Team's) deductive ability after attaining a sufficient level of a knowledge area. Wisdom therefore depends on knowledge. Examples: 'Ecosystem integrity is maintained'; 'Human well being is assured' 


\section{Box 1. Continued}

A criterion is defined as a principle or standard that a thing is judged by. A criterion can therefore be viewed as a second order principle, one that adds meaning and operationality to a principle without itself being a direct measure of performance. Criterion is the intermediate point to which the information provided by indicators can be integrated and where an interpretable assessment forms. Principle forms the final point of integration.

In addition to considering criterion to be the second order principle, it is a reflection of knowledge. Knowledge, moreover, is the accumulation of related information over a long period of time. It can be seen as a large scale selective combination or union of related pieces of information. For example, 'Primary functions of the forest ecosystem are maintained', 'Processes that maintain genetic diversity are conserved', 'Just access to benefits is assured'.

An indicator is any variable or component of the forest ecosystem or the relevant management systems used to infer attributes of the sustainability of the resources and its utilisation (Landres 1992). The transitive verb 'to indicate' is defined in the Concise Oxford Dictionary as: - point out, make known, show; or - be a sign or symptom of, express the presence of.

An indicator should convey a 'single meaningful message'. This 'single message' is termed information. It represents an aggregate of one or more data elements with certain established relationships. For examples: 'Seed sources are secure'; 'Directional change in allele or genotypic frequencies is low'; 'Conflict levels are low and not rising'.

A verifier is defined as data or information that enhances the specificity or the ease of assessment of an indicator. The forth level of specificity, verifier provides specific details that indicate or reflect a desired condition of an indicator. It adds meaning, precision and usually also site specificity to an indicator. It may define 


\section{Box 1. Continued}

the limits of hypothetical zone from which recovery can still safely take place (performance threshold/target). On the other hand, it may also be defined as procedures needed to determine satisfaction of the conditions postulated in the indicator concerned (means of verification).

At the bottom of the hierarchy are data elements. The relationship between data element and verifier is relatively close for performance thresholds (or targets) and is loose for means of verification. With this in mind it can be defined that the data element is a 'primitive' entity that conveys a "single value" (as opposed to a "single message" in the case of information). For examples: "Number of seed trees'; 'Number of alleles'; Number of court cases'.

\section{Spatial Levels}

This document uses two spatial levels to define management of plantation development. These are:

- $\quad$ Landscape Level - the entire area of the plantation estate.

- Stand Level - individual plantation units within the estate which are normally a single contiguous age class planting of the same species. 


\section{Introduction}

\subsection{The Problem}

Plantation development is on a rapid increase throughout the Tropics, and is one of the major reasons for current natural forest conversion. It is also an important factor affecting the state of biodiversity within these managed tropical forest landscapes and the people dependent on the resources within and/or living within those areas. This in itself would imply and suggest that considerable emphasis should be put on ensuring that ecological, environmental, and social adverse impacts and externalities should be minimized. Global and national concerns have also been raised concerning the role of plantations in global carbon sequestration and their impact on conservation of biodiversity.

In order to meet such demand sustainable plantation management is required. Plantation management should not be driven by an extractive philosophy (Nambiar and Brown 1997), which views plantation management and plantations as a separate entity from the surrounding, environment and socio economics of the local community. This provides an explanation for the reasons why many non-governmental organizations oppose plantations. First, there is the natural forest conversion issue. In those cases, where plantations are established through conversion of natural forests (such as in Indonesia), it is important to consider under what circumstances conversion from natural forest into plantations is appropriate. Second, there is biodiversity loss associated with plantation development. Conversion of natural forest will inevitably reduce biodiversity in the area, and natural forest conversion is the main reason for the current unprecedented rate of biodiversity loss. Third, the displacement of local indigenous communities who have been living in the area is another very serious issue, often leading to endless conflicts between plantation owners and the local people. Land limitation is also a problem for plantation expansion due to resistance from local people, and this often incurs large establishment and management costs (Potter and Lee 1998).

Sustainable plantation management implies consideration of long-term biological productivity, and environmental, social and economic factors linked with the business of forestry. 
Plantation sustainability is most likely if there is maximum alignment between key interdependent variables including: ecological capability of the site; intensity of management; soil, water and other environmental values; and economic benefit and social goals (Nambiar and Brown 1997).

Many externalities associated with plantations are related to improper and inappropriate management practices. Hence, new and more appropriate standards and practices are required to be developed. It is also important to develop general methods and mechanisms to ensure that these measures are implemented on the ground, as well as ensuring that subsequent assessment and monitoring of the state of the plantations are in place.

\subsection{The Purpose}

CIFOR convened a workshop at PT Riau Andalan Pulp and Paper (RAPP), a member of the APRIL Group, at Riau, Sumatra on 10-14 April 2000, to develop Criteria and Indicators and a Code of Practice for Industrial Tree Plantation Development in the Tropics. The focus of the workshop was on practices relevant in the development phase of large-scale timber plantations in the Tropics. Issues relevant at the landscape scale were emphasised (cf. Box 1). This workshop was the first attempt to develop a process designed to link the development of C\&I more closely with practical plantation development principles and practices (i.e., the Code). The aim was to ensure that the standards for practical and sustainable development of plantations properly and appropriately reflected the needs and concerns expressed in the criteria and indicators for the development of sustainable planted forests.

\subsection{Why Criteria and Indicators?}

The concept of C\&I was designed to be used in assessing the sustainability of forest management, and has been an evolving concept. Several approaches to C\&I or guidelines for sustainable forest management have been developed. For example, the International Tropical Timber Organisation (ITTO) launched criteria for the measurement of sustainable 
tropical forest management (SFM); the Worldwide Fund for Nature (WWF) and the International Union for the Conservation of Nature (IUCN) developed guidelines for timber plantations, environmental, social and cultural issues relating to commercial afforestation; the Forest Stewardship Council (FSC) introduced general principles and criteria for forest management; SmartWood Program of Rainforest Alliance released generic guidelines for SFM assessment; and Lembaga Ekolabel Indonesia (LEI) also developed C\&I for SFM of Indonesia forest.

In general, different sets of C\&I can be formulated to serve at various levels, namely global, regional (eco-regional), national, and sub-national or at Forest Management Unit (FMU) level.

Muhtaman and Siregar (2000) compiled and conducted an analysis of three different minimum sets of all C\&I resulting from three expert teams' efforts at three different industrial Acacia mangium plantations in Indonesia. This is a synthesis of these with an emphasis on the process of developing, and testing, criteria and indicator sets appropriate for the situation at each study site.

\subsection{Why a Code of Practice?}

The purpose of a Code of Practice is to provide:

- a set of minimum standards for improved practices for plantations;

- the capacity to fulfill the criteria and indicators for improved management of plantations;

- $\quad$ support the protection of sites of cultural, historical, archaeological, geomorphological, biological and spiritual significance;

- guidelines for resource areas for local communities;

- guidelines for biodiversity conservation measures for flora and fauna;

- $\quad$ support for promoting plantation productivity;

- $\quad$ support for improvement of the health and safety of forest workers;

- $\quad$ support for maximum economic return from plantations; and

- $\quad$ support for an equitable distribution of benefits from the forest. 
In itself, a Code of Practice does not ensure sustainable management, however, compliance with its standards will move plantation development operations closer to achieving SFM.

\subsection{Why Linking the Development of C\&I with Developing a Code of Practice?}

A general, and frequently raised, concern is that the development of C\&I for sustainable management of natural forests, did not sufficiently consider the practicality and relevance to forest managers.

The efforts to develop C\&I for sustainable management of plantations has just begun. Thus being in the early stages of the development of plantation C\&I, provides an opportunity to implement a different approach compared to that used for C\&I for natural forest management in many countries and by many organisations.

Through their forestry policies and/or environmental legislation, many tropical countries have provided strong support for sustainable forest management. It is hoped that the ability of countries to implement sustainable forest management in industrial tree plantations will be enhanced by the adoption of the Code of Practice for Industrial Tree Plantation Development in the Tropics and compliance with appropriate C\&I for plantation development. 


\section{Approach}

Two main sets of documents were used: a) a first draft Code of Practice for development of large-scale timber plantations in tropical Asia developed by a consultant, and b) existing documents and reports on C\&I for sustainable plantation management, developed by CIFOR and its collaborators, who produced the research reports (three country level case studies in the Tropics), used as background material for this present effort (Annexes 1, 2 and 3).

The development team consisted of experts in forest management, ecology, and socioeconomics, as well as expertise in C\&I, codes of practice, practical management and certification.

CIFOR scientists, and forestry experts from of Lembaga Ekolabel Indonesia, Lembaga Alam Tropika Indonesia (LATIN), Institut Pertanian Bogor (IPB), and RAPP's research and development and environment management group participated in the workshop. 


\section{Results and Discussion}

The previous sets of criteria and indicators (Annexes 1, 2 and 3) were re-evaluated and the suggested revised set of C\&I is shown in Table 1,2 and 3, and are discussed in the following sections.

Specific reference is made to the "Code of Practice for Industrial Tree Plantation Development in the Tropics" at the verifier level, by referring to the appropriate section number in the Code.

\subsection{C\&I for Social and Community Relationship Issues at Landscape Level}

The community within the Forest Management Unit has to be considered an important component of sustainability and the goal is to enhance human well-being of the local communities within and surrounding the plantation estate (Table 1).

\subsection{C\&I for Production Planning and Management Issues at Stand and Landscape level}

The approach has been to divide the C\&I according to two conceptual axes: a) as either production planning issues or management issues, and b) the spatial scale: stand or landscape level.

Production planning is relevant at both the landscape level and at the stand level. At both levels, production planning should aim at ensuring that that development process is in place to promote plantation sustainability (Table $2 \mathrm{a}$ and $2 \mathrm{~b}$ ). Management is usually conducted at the landscape level and should aim at (Table 2c). 


\subsection{Environmental Issues at Landscape Level}

The emphasis of the environmental concerns was considered relevant only at the landscape level. It was realized that any action or change in land use will have some impact on ecosystem function and performance. Sustainable forest management of plantations should aim at minimizing the negative impacts on ecosystem functions (Table 3 ). 


\section{C\&l for Plantations}

Table 1. The revised set of Criteria and Indicators for Sustainable Management of LargeScale Timber Plantations. The last entry in the verifier column referred to by section number relates to the Code of Practice for Industrial Tree Plantation Development in the Tropics.

\begin{tabular}{|c|c|c|}
\hline \multicolumn{3}{|c|}{ Social and Community Relationship Issues at landscape Level } \\
\hline \multicolumn{3}{|c|}{ Goal: Human well-being is enhanced } \\
\hline Criteria & Indicators & Verifiers \\
\hline \multirow[t]{3}{*}{$\begin{array}{l}\text { Stakeholder's tenure and land } \\
\text { use rights secured }\end{array}$} & $\begin{array}{l}\text { National and regional land use } \\
\text { plans specify the basis of } \\
\text { development }\end{array}$ & $\begin{array}{l}\text { - Area of plantation development } \\
\text { is consistent with approved } \\
\text { regional/National land use plans } \\
\text { (Sect. 2.1 Planning levels) }\end{array}$ \\
\hline & $\begin{array}{l}\text { - Process to determine land use at } \\
\text { landscape level }\end{array}$ & $\begin{array}{l}\text { Permanent forum consisting of } \\
\text { representatives from } \\
\text { concessionaires and } \\
\text { the community with decision } \\
\text { making powers } \\
\text { (Sect. 3.3.1 Security of tenure } \\
\text { and land use) }\end{array}$ \\
\hline & - Long term land use plan & $\begin{array}{l}\text { - Land use agreement is } \\
\text { prepared and signed by both } \\
\text { stakeholders (concessionaire } \\
\text { and community leaders) } \\
\text { (Sect. 3.3.1 Security of tenure } \\
\text { and land use) }\end{array}$ \\
\hline
\end{tabular}


Table 1. Continued

\begin{tabular}{|c|c|c|}
\hline \multirow[t]{2}{*}{ Criteria } & Indicators & Verifiers \\
\hline & $\begin{array}{l}\text { - Land use boundaries delineated } \\
\text { and demarcated }\end{array}$ & $\begin{array}{l}\text { - Up to date GIS and maps } \\
\text { - Permanent boundary markers } \\
\text { located with community } \\
\text { representatives in } \\
\text { accordance with the GIS } \\
\text { (Sect. } 3.3 .1 \text { Security of tenure } \\
\text { and land-use) }\end{array}$ \\
\hline & $\begin{array}{l}\text { - Opportunity for local } \\
\text { communities to access forest } \\
\text { concession area }\end{array}$ & $\begin{array}{l}\text { - Products and services access } \\
\text { agreement is prepared and } \\
\text { signed by the forum members } \\
\text { (concessionaire and community } \\
\text { leaders) } \\
\text { (Sect. } 3.3 .1 \text { Security of tenure } \\
\text { and land-use) }\end{array}$ \\
\hline & $\begin{array}{l}\text { Opportunity for local } \\
\text { communities to receive } \\
\text { compensation for loss of } \\
\text { use of land and other resources } \\
\text { in the concession area }\end{array}$ & $\begin{array}{l}\text { - Letter of compensation outlining } \\
\text { details provided by } \\
\text { concessionaire and signed by } \\
\text { forum members } \\
\text { (Sect. 3.3.1 Security of tenure } \\
\text { and land-use) }\end{array}$ \\
\hline $\begin{array}{l}\text { Stakeholders actively involved } \\
\text { in forest planning, } \\
\text { management and monitoring }\end{array}$ & $\begin{array}{l}\text { - Fair and effective mechanism } \\
\text { for conflict resolution }\end{array}$ & $\begin{array}{l}\text { - Permanent participatory forum } \\
\text { consisting of representatives from } \\
\text { concessionaires and the } \\
\text { community and related parties } \\
\text { with decision making power } \\
\text { (Sect. } 3.3 .2 \text { Stakeholder } \\
\text { involvement) }\end{array}$ \\
\hline
\end{tabular}


Table 1. Continued

\begin{tabular}{|c|c|c|}
\hline Criteria & Indicators & Verifiers \\
\hline & $\begin{array}{l}\text { - Local communities are provided } \\
\text { appropriate and relevant } \\
\text { information necessary for forest } \\
\text { planning }\end{array}$ & $\begin{array}{l}\text { - Information provided in user } \\
\text { friendly format through written } \\
\text { material and village meetings } \\
\text { by concessionaire } \\
\text { representatives } \\
\text { (Sect. } 3.3 .2 \text { Stakeholder } \\
\text { involvement) }\end{array}$ \\
\hline & $\begin{array}{l}\text { - Concessionaires to adequately } \\
\text { take account of local knowledge } \\
\text { in the forest planning activities }\end{array}$ & $\begin{array}{l}\text { - Information provided to } \\
\text { concessionaires through field } \\
\text { visits and village meetings with } \\
\text { planning documents provided } \\
\text { to village communities } \\
\text { (Sect. } 3.3 .2 \text { Stakeholder } \\
\text { involvement) }\end{array}$ \\
\hline & $\begin{array}{l}\text { Professional staff for community } \\
\text { development is available and } \\
\text { fully supported by the } \\
\text { management }\end{array}$ & $\begin{array}{l}\text { - Development of a Community } \\
\text { Development Section with } \\
\text { appropriate community } \\
\text { development officers and } \\
\text { supported with sufficient funding } \\
\text { (Sect. } 3.3 .2 \text { Stakeholder } \\
\text { involvement) }\end{array}$ \\
\hline & $\begin{array}{l}\text { Contribution to the maintenance } \\
\text { of cultural values and diversity, } \\
\text { and of indigenous and local } \\
\text { knowledge }\end{array}$ & $\begin{array}{l}\text { - Protect, monitor and document } \\
\text { cultural sites and support } \\
\text { traditional cultural activities as } \\
\text { part of the community } \\
\text { development programme } \\
\text { (Sect. } 3.3 .2 \text { Stakeholder } \\
\text { involvement) }\end{array}$ \\
\hline
\end{tabular}


Table 1. Continued

\begin{tabular}{|c|c|c|}
\hline Criteria & Indicators & Verifiers \\
\hline \multirow[t]{4}{*}{$\begin{array}{l}\text { Socio-economic benefits for } \\
\text { local communities directly } \\
\text { impacted by the concession } \\
\text { activities are maximised }\end{array}$} & $\begin{array}{l}\text { - Local communities have } \\
\text { significant opportunities for } \\
\text { employment and income } \\
\text { generation }\end{array}$ & $\begin{array}{l}\text { Concessionaires to maximise } \\
\text { opportunity for employment } \\
\text { and income generation for } \\
\text { local communities in } \\
\text { plantation and associated } \\
\text { activities } \\
\text { (Sect. 3.3.3 Economics for local } \\
\text { communities) }\end{array}$ \\
\hline & $\begin{array}{l}\text { - Local communities are } \\
\text { encouraged to grow timber on } \\
\text { their own land to supply wood } \\
\text { needed for the processing mill }\end{array}$ & $\begin{array}{l}\text { - If a processing mill exists, } \\
\text { concessionaires develop and } \\
\text { provide support to out grower } \\
\text { schemes for supply of wood as } \\
\text { part for community } \\
\text { development program } \\
\text { (Sect. } 3.3 .3 \text { Economics for local } \\
\text { communities) }\end{array}$ \\
\hline & $\begin{array}{l}\text { Development of community } \\
\text { infrastructure and services } \\
\text { should meet local community's } \\
\text { needs and priorities }\end{array}$ & $\begin{array}{l}\text { - Forum consisting of representatives } \\
\text { from concessionaires and the } \\
\text { community with decision } \\
\text { making powers to determine } \\
\text { needs and priorities } \\
\text { (Sect. } 3.3 .3 \text { Economics for local } \\
\text { communities) }\end{array}$ \\
\hline & $\begin{array}{l}\text { - Assist with the development of } \\
\text { the capacity of local } \\
\text { communities to undertake } \\
\text { alternative income } \\
\text { generating activities }\end{array}$ & $\begin{array}{l}\text { - Concessionaires to provide } \\
\text { training and support for income } \\
\text { generation, including } \\
\text { improved farming } \\
\text { practices and marketing and } \\
\text { business development } \\
\text { (Sect. } 3.3 .3 \text { Economics for local } \\
\text { communities) }\end{array}$ \\
\hline
\end{tabular}


Table 1. Continued

\begin{tabular}{|c|c|c|}
\hline \multirow[t]{3}{*}{ Criteria } & Indicators & Verifiers \\
\hline & $\begin{array}{l}\text { Education and training of local } \\
\text { communities to assist with } \\
\text { capacity building, income } \\
\text { generation and enhanced } \\
\text { employment opportunities }\end{array}$ & $\begin{array}{l}\text { - Concessionaires to provide } \\
\text { formal and vocational training } \\
\text { as determined by the forum } \\
\text { (Sect. } 3.3 .3 \text { Economics for local } \\
\text { communities) }\end{array}$ \\
\hline & $\begin{array}{l}\text { - Local communities to have } \\
\text { access through cooperatives or } \\
\text { similar organisations to share } \\
\text { holdings } \\
\text { - Community health indicators, } \\
\text { example: access and medial/ } \\
\text { health services }\end{array}$ & $\begin{array}{l}\text { - Preferential share holdings for } \\
\text { cooperatives, may be issued for } \\
\text { cooperatives or similar } \\
\text { organisations } \\
\text { (Sect. } 3.3 .3 \text { Economics for local } \\
\text { communities) }\end{array}$ \\
\hline \multirow[t]{3}{*}{$\begin{array}{l}\text { Responsibility of primary } \\
\text { stakeholders is well defined }\end{array}$} & $\begin{array}{l}\text { Verification between local } \\
\text { communities and the } \\
\text { concessionaire regarding rights } \\
\text { and responsibilities of both } \\
\text { parties }\end{array}$ & $\begin{array}{l}\text { - Document or MOU stating the } \\
\text { rights and responsibilities of } \\
\text { both parties ratified by the } \\
\text { forum and presented to the } \\
\text { communities } \\
\text { (Sect. } 3.3 .4 \text { Responsibility of } \\
\text { stakeholders) }\end{array}$ \\
\hline & $\begin{array}{l}\text { Government health and safety } \\
\text { standards are met or if non } \\
\text { existent, the ILO Guidelines to } \\
\text { apply (applicable toemployees) }\end{array}$ & $\begin{array}{l}\text { - Concessionaires have } \\
\text { guidelines on work place health } \\
\text { and safety and a mechanism to } \\
\text { ensure compliance } \\
\text { (Sect. } 11.2 \text { Personnel safety } \\
\text { requirements; Sect. } 11.3 \\
\text { Equipment safety requirements) }\end{array}$ \\
\hline & $\begin{array}{l}\text { - Regional government wage and } \\
\text { employment conditions are met }\end{array}$ & $\begin{array}{l}\text { - Concessionaires will adhere to } \\
\text { minimal wage and conditions } \\
\text { and maintain payroll and } \\
\text { contract documentation } \\
\text { (Sect. } 11.1 \text { Working conditions) }\end{array}$ \\
\hline
\end{tabular}


Table 1. Continued

\begin{tabular}{|c|c|c|}
\hline Criteria & Indicators & Verifiers \\
\hline & $\begin{array}{l}\text { - Career development plan based } \\
\text { on equal opportunity }\end{array}$ & $\begin{array}{l}\text { - Concessions develop and } \\
\text { maintain an equal opportunity } \\
\text { career plan for employees } \\
\text { (Sect. } 11.1 \text { Working conditions) }\end{array}$ \\
\hline & $\begin{array}{l}\text { - Concessionaires to have a process } \\
\text { of informing communities of the } \\
\text { physical and social } \\
\text { environmental impact of } \\
\text { plantations }\end{array}$ & $\begin{array}{l}\text { - Community development program } \\
\text { that includes village meetings to } \\
\text { inform communities on } \\
\text { environmental impact of } \\
\text { plantations } \\
\text { (Sect. 3.3.4 Responsibility of } \\
\text { stakeholders) }\end{array}$ \\
\hline & $\begin{array}{l}\text { Workers rights to organise and } \\
\text { negotiate and receive } \\
\text { compensation for loss or damage }\end{array}$ & $\begin{array}{l}\text { - Concessionaires provide } \\
\text { evidence of policies and } \\
\text { procedures which enable workers } \\
\text { to negotiate with management } \\
\text { (Sect. } 11.1 \text { Working conditions) }\end{array}$ \\
\hline
\end{tabular}


Table 2a. The revised set of Criteria and Indicators for Sustainable Management of LargeScale Timber Plantations. The last entry in the verifier column referred to by section number relates to the Code of Practice for Industrial Tree Plantation Development in the Tropics. Cf. Annex 2, and Table $2 \mathrm{~b}$ and $2 \mathrm{c}$.

\section{Production Planning Issues at Landscape Level}

Goal: Development process/system is in place to promote plantation sustainability

\begin{tabular}{|c|c|c|}
\hline Criteria & Indicators & Verifiers \\
\hline $\begin{array}{l}\text { A comprehensive } \\
\text { Landscape Level } \\
\text { Plan is available }\end{array}$ & $\begin{array}{l}\text { Management objec- } \\
\text { tives are clearly defined } \\
\text { and stated. }\end{array}$ & $\begin{array}{l}\text { - Company provides documentation } \\
\text { which includes policy statements and } \\
\text { management objectives. } \\
\text { - Landscape level plan prepared with } \\
\text { consideration of broader regional and } \\
\text { national environmental (SFM) priorities. }\end{array}$ \\
\hline & $\begin{array}{l}\text { A Landscape Level } \\
\text { Plan is prepared that } \\
\text { meets environmental, } \\
\text { community and } \\
\text { production require- } \\
\text { ments and needs. }\end{array}$ & $\begin{array}{l}\text { (Not covered by Code) } \\
\text { - Forest map produced using aerial photograph } \\
\text { interpretation, satellite imagery and ground } \\
\text { inspection as appropriate. } \\
\text { - Broad, ground based timber inventory to } \\
\text { determine timber volume on future plantation } \\
\text { and existing plantation areas. } \\
\text { - Acceptable map accuracy is determined with } \\
\text { GPS or other method. } \\
\text { - Environmental, community and production } \\
\text { requirements overlain on the map including } \\
\text { buffers, settlements, conservation areas, } \\
\text { cultural areas, road system layout, plantation } \\
\text { unit locations, fire breaks, log ponds, quarries. } \\
\text { (Sect. } 3 \text { Landscape level planning) }\end{array}$ \\
\hline
\end{tabular}


Table 2a. Continued

\begin{tabular}{|c|c|c|}
\hline Criteria & Indicators & Verifiers \\
\hline & $\begin{array}{l}\text { - Sound silvicultural systems are } \\
\text { developed. }\end{array}$ & $\begin{array}{l}\text { - Manual or standard operating } \\
\text { procedures detailing silvicultural } \\
\text { systems for harvesting planting } \\
\text { and maintenance are } \\
\text { documented. } \\
\text { (Not covered by Code) }\end{array}$ \\
\hline & $\begin{array}{l}\text { Plan for resource requirements } \\
\text { and allocation (i.e. financial, } \\
\text { human, machine and land) } \\
\text { according to the Landscape } \\
\text { Level Plan. }\end{array}$ & $\begin{array}{l}\text { - Documented resource allocation } \\
\text { plan identifying any deficiencies } \\
\text { and mechanisms for overcoming } \\
\text { these deficiencies } \\
\text { (Sect. } 3 \text { \& } 4 \text { Landscape and } \\
\text { Stand level planning) }\end{array}$ \\
\hline $\begin{array}{l}\text { The Landscape Level } \\
\text { Management Plan is } \\
\text { effectively implemented }\end{array}$ & $\begin{array}{l}\text { - External boundary is lawfully and } \\
\text { permanently delineated on the } \\
\text { map and demarcated on the } \\
\text { ground as agreed with } \\
\text { stakeholders. }\end{array}$ & $\begin{array}{l}\text { - Agreement with stakeholders on } \\
\text { location of external plantation } \\
\text { boundaries. } \\
\text { - Accurate marking of boundary on } \\
\text { map and ground } \\
\text { (Sect. } 3.3 .1 \text { Security of tenure } \\
\text { and landuse) }\end{array}$ \\
\hline $\begin{array}{l}\text { A comprehensive research and } \\
\text { development program is in } \\
\text { place or alternate systems } \\
\text { utilised }\end{array}$ & $\begin{array}{l}\text { Research and development } \\
\text { program to support operational } \\
\text { activities is established internally } \\
\text { or acquired externally and } \\
\text { practiced. }\end{array}$ & $\begin{array}{l}\text { - External knowledge or technology } \\
\text { is acquired. } \\
\text { - Plan for a research and } \\
\text { development program developed } \\
\text { with clearly defined goals which } \\
\text { are regularly reviewed. } \\
\text { (Not covered by Code) }\end{array}$ \\
\hline $\begin{array}{l}\text { Effective monitoring and } \\
\text { auditing systems to check } \\
\text { conformity with Landscape } \\
\text { Level Plan }\end{array}$ & $\begin{array}{l}\text { - Documentation and records of all } \\
\text { forest management activities are } \\
\text { kept for monitoring purposes. }\end{array}$ & $\begin{array}{l}\text { - Records can be retrieved for all } \\
\text { management activities } \\
\text { (Sect. } 2.2 \text { Requirements for } \\
\text { effective planning) }\end{array}$ \\
\hline
\end{tabular}


Table 2b. The revised set of Criteria and Indicators for Sustainable Management of LargeScale Timber Plantations. The last entry in the verifier column referred to by section number relates to the Code of Practice for Industrial Tree Plantation Development in the Tropics. Cf. Annex 2, and Table 2a and 2c.

\begin{tabular}{|c|c|c|}
\hline \multicolumn{3}{|c|}{ Production Planning Issues at Stand Level } \\
\hline \multicolumn{3}{|c|}{ Goal: Development system is in place to promote plantation sustainability } \\
\hline Criteria & Indicators & Verifiers \\
\hline \multirow[t]{2}{*}{$\begin{array}{l}\text { Appropriate Stand Level plans } \\
\text { developed }\end{array}$} & $\begin{array}{l}\text { - A Stand Level Plan map is } \\
\text { developed based on the } \\
\text { Landscape Level Plan and field } \\
\text { inspection. }\end{array}$ & $\begin{array}{l}\text { - Map produced showing boundary, } \\
\text { exclusion zones, buffer zones, } \\
\text { infrastructure and quarries } \\
\text { (Sect. } 4 \text { Stand level planning) }\end{array}$ \\
\hline & $\begin{array}{l}\text { - Planting program detailing } \\
\text { monthly planting targets, } \\
\text { operational schedules, manpower, } \\
\text { infrastructure and machinery/ } \\
\text { equipment requirements. }\end{array}$ & $\begin{array}{l}\text { Documentation detailing } \\
\text { operational schedules and } \\
\text { resource requirements/allocation } \\
\text { to meet targets } \\
\text { (Sect. } 4 \text { Stand level planning) }\end{array}$ \\
\hline \multirow[t]{3}{*}{$\begin{array}{l}\text { Operational activities comply } \\
\text { with plans }\end{array}$} & $\begin{array}{l}\text { Operations at the Stand Level } \\
\text { comply with both the Landscape } \\
\text { and Stand Level Plan. }\end{array}$ & $\begin{array}{l}\text { - Field inspections of on ground } \\
\text { operation to verify compliance with } \\
\text { details on the map and plan } \\
\text { (Sect. 8.8 Monitoring and } \\
\text { evaluation) }\end{array}$ \\
\hline & - Demarcation of individual stands. & $\begin{array}{l}\text { Boundary of stands clearly marked } \\
\text { on the ground } \\
\text { (Sect. } 8.2 \text { Pre harvest activity; } \\
\text { Sect. } 4 \text { Stand level planning) }\end{array}$ \\
\hline & $\begin{array}{l}\text { Site preparation techniques } \\
\text { ensuring minimal soil compaction, } \\
\text { displacement and erosion control }\end{array}$ & $\begin{array}{l}\text { - Low soil impact machinery (i.e. Low } \\
\text { ground pressure) used on site } \\
\text { - Minimum machinery activity, } \\
\text { maneuvers and passes on the site } \\
\text { - Utilisation of slash and debris on } \\
\text { skid tracks should be maximised }\end{array}$ \\
\hline
\end{tabular}


Table 2b. Continued

\begin{tabular}{|c|c|c|}
\hline Criteria & Indicators & Verifiers \\
\hline & & $\begin{array}{l}\text { - Use of machine blading or other } \\
\text { soil disturbance must be minimised } \\
\text { - Maximise protection of natural } \\
\text { ground cover and slash on site and } \\
\text { minimise vegetation disturbance } \\
\text { within the inter-rows } \\
\text { - If ripping or mounding then } \\
\text { must be done along the contour } \\
\text { (Sect. } 8 \text { Development at the stand } \\
\text { Level; Sect. } 10 \text { Plantation } \\
\text { establishment) }\end{array}$ \\
\hline & $\begin{array}{l}\text { Minimal burning should be } \\
\text { practiced (aim for zero burning) }\end{array}$ & $\begin{array}{l}\text { - Field checking to verify minimal } \\
\text { burning } \\
\text { (Sect. } 8.8 \text { Monitoring and } \\
\text { evaluation; Sect. } 10 \text { Plantation } \\
\text { establishment) }\end{array}$ \\
\hline & $\begin{array}{l}\text { - Preplanning to ensure adequate } \\
\text { seed and seedling availability for } \\
\text { plantation establishment }\end{array}$ & $\begin{array}{l}\text { - Documented nursery plan } \\
\text { detailing seed/seedling/cutting } \\
\text { requirements } \\
\text { (Not covered by Code) }\end{array}$ \\
\hline & $\begin{array}{l}\text { - High standard of planting and } \\
\text { tending operations }\end{array}$ & $\begin{array}{l}\text { - } 90 \% \text { survival after } 1 \text { month } \\
\text { (replacement of dead trees may } \\
\text { have occurred) } \\
\text { (Sect. } 10.3 \text { Planting) }\end{array}$ \\
\hline
\end{tabular}


Table 2b. Continued

\begin{tabular}{|c|c|c|}
\hline Criteria & Indicators & Verifiers \\
\hline & $\begin{array}{l}\text { Appropriate use of chemicals, } \\
\text { pesticides and fertilisers }\end{array}$ & $\begin{array}{l}\text { - Minimal usage of pesticides, } \\
\text { herbicides and fertilisers to } \\
\text { achieve management objectives } \\
\text { - Utilisation of alternatives to } \\
\text { pesticides, herbicide and fertiliser } \\
\text { wherever possible } \\
\text { - Application at appropriate times } \\
\text { of the year and during appropriate } \\
\text { weather conditions } \\
\text { - Application of pesticide, } \\
\text { herbicide in accordance with } \\
\text { best practice requirements } \\
\text { - Appropriate safety equipment } \\
\text { supplied to and worn by the worker } \\
\text { (Sect. } 10.4 \text { Herbicide and } \\
\text { pesticide application; Sect. } 10.5 \\
\text { Fertiliser application; Sect. } \mathbf{1 0 . 6} \\
\text { Alternatives to herbicides/ } \\
\text { pesticides/fertiliser) }\end{array}$ \\
\hline & - Exclusion zones are maintained & $\begin{array}{l}\text { - Field checking of Exclusion Zones } \\
\text { for confirmation that they are being } \\
\text { maintained } \\
\text { (Sect. } 8.8 \text { Monitoring and } \\
\text { evaluation) }\end{array}$ \\
\hline
\end{tabular}


Table 2c. The revised set of Criteria and Indicators for Sustainable Management of LargeScale Timber Plantations. The last entry in the verifier column referred to by section number relates to the Code of Practice for Industrial Tree Plantation Development in the Tropics. Cf. Annex 2, and Table $2 \mathrm{a}$ and $2 \mathrm{~b}$.

\begin{tabular}{|c|c|c|}
\hline \multicolumn{3}{|c|}{ Management Issues at Landscape Level } \\
\hline Criteria & Indicators & Verifiers \\
\hline \multirow[t]{2}{*}{$\begin{array}{l}\text { Best practice operations } \\
\text { developed, implemented and } \\
\text { maintained }\end{array}$} & $\begin{array}{l}\text { - Growth and yield data from } \\
\text { inventory plots and appropriate } \\
\text { inventory assessment systems to } \\
\text { monitor volume/yield trends }\end{array}$ & $\begin{array}{l}\text { - Inventory plots are established and } \\
\text { regularly measured } \\
\text { - Appropriate inventory carried out } \\
\text { on a regular basis } \\
\text { - Inventory plots and inventory data } \\
\text { used to determine volumes and } \\
\text { yield overtime } \\
\text { (Not covered by Code) }\end{array}$ \\
\hline & $\begin{array}{l}\text { - Data collection, storage and } \\
\text { reporting systems are developed } \\
\text { and effectively used }\end{array}$ & $\begin{array}{l}\text { - Data records readily available and } \\
\text { accessible } \\
\text { - Reports available based on the } \\
\text { data records } \\
\text { - Results of reports incorporated to } \\
\text { management policy and practices } \\
\text { (Not covered by Code) }\end{array}$ \\
\hline \multirow[t]{2}{*}{$\begin{array}{l}\text { Fire is managed and controlled } \\
\text { in the area }\end{array}$} & $\begin{array}{l}\text { - Fire Management Plan is in } \\
\text { place, including emergency } \\
\text { preparedness and drills }\end{array}$ & $\begin{array}{l}\text { - Fire Management Plan has been } \\
\text { developed and implemented } \\
\text { (Sect. } 12 \text { Fire management) }\end{array}$ \\
\hline & $\begin{array}{l}\text { - If fire is used for management } \\
\text { then it is controlled and any } \\
\text { uncontrolled fire is extinguished } \\
\text { or excluded from the } \\
\text { management area }\end{array}$ & $\begin{array}{l}\text { - Operational system of forest fire } \\
\text { prevention and suppression is } \\
\text { implemented } \\
\text { (Sect. } 12.2 \text { Preparation) }\end{array}$ \\
\hline
\end{tabular}


Table 2c. Continued

\begin{tabular}{|c|c|c|}
\hline Criteria & Indicators & Verifiers \\
\hline $\begin{array}{l}\text { Forest pest and disease } \\
\text { management practiced }\end{array}$ & $\begin{array}{l}\text { - Appropriate integrated } \\
\text { pest and disease } \\
\text { management program is } \\
\text { practiced }\end{array}$ & $\begin{array}{l}\text { - Census or monitoring records of pests and } \\
\text { diseases if applicable } \\
\text { - Incorporation of natural and/or biological } \\
\text { controls wherever possible before using } \\
\text { chemicals } \\
\text { - Mechanism for integrated pest and disease } \\
\text { management system development in } \\
\text { place } \\
\text { - Application of chemicals in accordance } \\
\text { with best practice requirements } \\
\text { (Sect. } \mathbf{1 0 . 4} \text { Herbicide and pesticide } \\
\text { application; Sect. } \mathbf{1 0 . 6} \text { Alternatives to } \\
\text { herbicides/pesticides/fertiliser) }\end{array}$ \\
\hline $\begin{array}{l}\text { Forest security and integrity is } \\
\text { maintained }\end{array}$ & $\begin{array}{l}\text { - Operational system of } \\
\text { forest security is } \\
\text { implemented }\end{array}$ & $\begin{array}{l}\text { - Plan developed for forest security } \\
\text { - Plan for forest security implemented } \\
\text { (Not covered by Code) }\end{array}$ \\
\hline \multirow[t]{2}{*}{$\begin{array}{l}\text { Professional and dedicated } \\
\text { human resource program } \\
\text { developed and continually } \\
\text { improved }\end{array}$} & $\begin{array}{l}\text { - Adequate human } \\
\text { resources at all levels of } \\
\text { management }\end{array}$ & $\begin{array}{l}\text { - Annual appraisal record of human } \\
\text { resources is available identifying } \\
\text { any deficiencies in staff capability } \\
\text { or number } \\
\text { - Any identified deficiencies addressed } \\
\text { (Sect. } 11.1 \text { Working conditions) }\end{array}$ \\
\hline & $\begin{array}{l}\text { - Clear organization } \\
\text { structure with job } \\
\text { description is developed }\end{array}$ & $\begin{array}{l}\text { - Organisational structure } \\
\text { developed and available } \\
\text { - Job descriptions developed for each } \\
\text { position } \\
\text { (Sect. } 11.1 \text { Working conditions) }\end{array}$ \\
\hline
\end{tabular}


Table 2c. Continued

\begin{tabular}{|c|c|c|}
\hline Criteria & Indicators & Verifiers \\
\hline \multirow[t]{3}{*}{$\begin{array}{l}\text { Appropriate safety guidelines } \\
\text { and procedures developed for } \\
\text { operations }\end{array}$} & $\begin{array}{l}\text { Operational guidelines for all } \\
\text { work practices including standard } \\
\text { safety procedures/equipment for } \\
\text { handling chemicals, vehicles, } \\
\text { harvest activities and utilisation } \\
\text { of machinery }\end{array}$ & $\begin{array}{l}\text { - Standard operating procedures } \\
\text { detailing safety requirements } \\
\text { documented for all operational } \\
\text { activities } \\
\text { (Sect. } 11.2 \text { Personnel safety } \\
\text { requirements; Sect. } 11.3 \\
\text { Equipment safety requirements) }\end{array}$ \\
\hline & $\begin{array}{l}\text { - Appropriate training in safety } \\
\text { guidelines and safe working } \\
\text { practices }\end{array}$ & $\begin{array}{l}\text { - Development of appropriate } \\
\text { training systems based on standard } \\
\text { operating procedures. } \\
\text { - Training programs run for staff in } \\
\text { their relevant job area } \\
\text { (Sect. } 11.1 \text { Working conditions) }\end{array}$ \\
\hline & $\begin{array}{l}\text { Procedures identified for accident } \\
\text { investigation and analysis to } \\
\text { determine procedures for future } \\
\text { accident prevention }\end{array}$ & $\begin{array}{l}\text { - Maintenance of statistical } \\
\text { records of accidents } \\
\text { - System for accident identification } \\
\text { - investigation and reporting } \\
\text { - Mechanism for incorporating } \\
\text { identified accident prevention } \\
\text { measures into standard operating } \\
\text { procedures } \\
\text { (Sect. } \mathbf{1 1 . 1} \text { Working conditions) }\end{array}$ \\
\hline
\end{tabular}


Table 3. The revised set of Criteria and Indicators for Sustainable Management of LargeScale Timber Plantations. The last entry in the verifier column referred to by section number relates to the Code of Practice for Industrial Tree Plantation Development in the Tropics. Cf. Annex 3.

\begin{tabular}{|c|c|c|}
\hline \multicolumn{3}{|c|}{ Environmental Issues at Landscape Level } \\
\hline Goal: To minimise & e impact on ecosystem func & \\
\hline Criteria & Indicators & Verifiers \\
\hline \multirow[t]{3}{*}{$\begin{array}{l}\text { Impact on structure and } \\
\text { ecosystem function is } \\
\text { minimised }\end{array}$} & $\begin{array}{l}\text { Exclusion and Conservation Zones } \\
\text { are developed according to Best } \\
\text { Practice }\end{array}$ & $\begin{array}{l}\text { - Government rules with respect to } \\
\text { Exclusion Zones are adhered to } \\
\text { - A Landscape Level Plan is } \\
\text { prepared detailing Exclusion } \\
\text { Zones } \\
\text { (Sect. } 3.5 \text { Exclusion zones for } \\
\text { landscape level planning) }\end{array}$ \\
\hline & $\begin{array}{l}\text { Habitat trees are retained in } \\
\text { plantation production areas where } \\
\text { appropriate for wildlife }\end{array}$ & $\begin{array}{l}\text { - Government rules with respect to } \\
\text { Habitat trees are adhered to } \\
\text { (Sect. } 3 \text { Landscape level } \\
\text { planning; Sect. } 4 \text { Stand level } \\
\text { planning; Sect. } 3.5 \text { Exclusion } \\
\text { zones for landscape level } \\
\text { planning) }\end{array}$ \\
\hline & $\begin{array}{l}\text { - Endangered flora and fauna on } \\
\text { international (CITES) and country } \\
\text { lists are protected } \\
\text { - Endangered flora and fauna on } \\
\text { local and regional and lists are } \\
\text { protected. }\end{array}$ & $\begin{array}{l}\text { - National rules with respect to } \\
\text { - Endangered flora and fauna are } \\
\text { adhered to } \\
\text { (Sect. } 3 \text { Landscape level } \\
\text { planning; Sect. } 4 \text { Stand level } \\
\text { planning; Sect. } 3.5 \text { Exclusion } \\
\text { zones for landscape level } \\
\text { planning) }\end{array}$ \\
\hline
\end{tabular}


Table 3. Continued

\begin{tabular}{|c|c|c|}
\hline Criteria & Indicators & Verifiers \\
\hline \multirow[t]{3}{*}{$\begin{array}{l}\text { The adverse impact on soil } \\
\text { and water resources is } \\
\text { minimised }\end{array}$} & $\begin{array}{l}\text { - Soil disturbance is minimised } \\
\text { - Exposure of bare soil is } \\
\text { minimised after harvesting until } \\
\text { replanting }\end{array}$ & $\begin{array}{l}\text { - Best practice implemented in: } \\
\text { - Road design } \\
\text { - Road construction } \\
\text { - Harvesting operations } \\
\text { - Site preparation and clearing at } \\
\text { the stand level } \\
\text { - Minimal use of fire for site } \\
\text { preparation } \\
\text { (Sect. } 5 \text { Roading and drainage; } \\
\text { Sect. } 6 \text { Road and watercourse } \\
\text { crossings; Sect. } 7 \text { Quarries; } \\
\text { Sect. } 9 \text { Development at stand } \\
\text { level) }\end{array}$ \\
\hline & $\begin{array}{l}\text { Judicious use of chemical for pest, } \\
\text { disease, and weed management, } \\
\text { and fertilizer }\end{array}$ & $\begin{array}{l}\text { - Best practices in use and } \\
\text { handling of: } \\
\text { - Pesticides } \\
\text { - Fertilizers } \\
\text { (Sect. } 10.4 \text { Herbicide and } \\
\text { pesticide application; Sect. } 10.5 \\
\text { Fertilizer application) }\end{array}$ \\
\hline & $\begin{array}{l}\text { - Negative impact on water quality } \\
\text { and quantity is minimised } \\
\text { - Erosion and siltation are } \\
\text { minimised }\end{array}$ & $\begin{array}{l}\text { - Reduce water pollution and } \\
\text { minimise incidence of flash } \\
\text { - Improved due to clearing of areas by: } \\
\text { - Improved road construction } \\
\text { - Appropriate road watercourse } \\
\text { crossings } \\
\text { - Best practices in harvesting } \\
\text { operations and site preparation }\end{array}$ \\
\hline
\end{tabular}


Table 3. Continued

\begin{tabular}{|c|c|c|}
\hline Criteria & Indicators & Verifiers \\
\hline & & $\begin{array}{l}\text { - Minimum use of fire in site } \\
\text { preparation } \\
\text { (Sect. } 5 \text { Roading and drainage; } \\
\text { Sect. } 6 \text { Road and watercourse } \\
\text { crossings; Sect. } 7 \text { Quarries; } \\
\text { Sect. } 9 \text { Development at stand } \\
\text { level) }\end{array}$ \\
\hline & $\begin{array}{l}\text { - Reduced risk of fire in and around } \\
\text { plantations. }\end{array}$ & $\begin{array}{l}\text { - Appropriate Fire Protection and } \\
\text { - Adequate and operable fire } \\
\text { prevention and suppression } \\
\text { equipment } \\
\text { - Adequate numbers and quality of } \\
\text { staff trained in fire management } \\
\text { - Minimal burning of residual after } \\
\text { harvesting as a result of appropriate } \\
\text { harvesting operation } \\
\text { - No burning on peat soils } \\
\text { (Sect. } 12 \text { Fire management) }\end{array}$ \\
\hline & $\begin{array}{l}\text { - Minimal ponding or water } \\
\text { logging as a result of poor forest } \\
\text { planning and management }\end{array}$ & $\begin{array}{l}\text { - Best practices in } \\
\text { - Road construction (drainage } \\
\text { important) } \\
\text { - Watercourse crossings and } \\
\text { maintenance } \\
\text { - Log landings } \\
\text { (Sect. } 5.3 \text { Road and access track } \\
\text { construction; Sect. } 6 \text { Road } \\
\text { watercourse crossings; Sect. } 8.3 \\
\text { Log landings) }\end{array}$ \\
\hline
\end{tabular}




\section{Conclusions and Recommendations}

1. In general, the hierarchical C\&I structure itself was compatible with that relevant to management.

2. For the social and ecological/environmental issues, the existing C\&I structure was largely accepted, though the exact wording was revised in some cases.

3. The structure of the management C\&I were the most problematic. First, it was recognised that the issues involved in a) management, and b) production planning, are different, and furthermore are often handled by different parts of the company. Production Planning issues (Table $2 \mathrm{a}$ and 2b) and Management issues (Table 2c) therefore formed the basis for the revised set of C\&I. Second, it was recognised that production planning occurs at two levels, both at the landscape level and at the stand level. Thus, separate sets of C\&I were developed for the landscape and the stand level, respectively (Table $2 \mathrm{a}$ and Table $2 \mathrm{~b}$, respectively).

4. For most issues of C\&I, a direct link to an appropriate section of the Code was possible.

5. The main gaps in linking the C\&I with the Code was found with respect to production planning issues at both landscape level and stand level (cf. Table $2 \mathrm{a}$ and $2 \mathrm{~b}$ ), and for management issues at the landscape level (Table 2c). Future efforts to develop appropriate sections within the Code is therefore recommended. 
6. The present report was based on extensive expert opinions and insights, as well as published syntheses. It is recommended that the applicability and transferability of this approach and the associated results, are tested at several sites. A desirable testing scenario is:

- Asia: one more site, e.g., in the Philippines.

- Sub-Saharan Africa: Congo?

- Latin/South America: Brasil? - extensive C\&I work has already taken place there. 


\section{References Cited}

CIFOR. 1997. Guidelines for developing, testing and selecting criteria and indicators for sustainable forest management. CIFOR, Bogor, Indonesia.

Dudley, N. 1997. Guidelines for timber plantations, environmental, social and cultural issues relating to commercial afforestation (draft). A report for WWF and IUCN. Equilibrium, UK. 73p.

Forest Stewardship Council (FSC). 2000. FSC Principles and Criteria. http://www.fscoax.org (Revised February 2000).

International Tropical Timber Organization (ITTO). 1993. ITTO guidelines for the establishment and sustainable management of planted tropical forests. ITTO Policy Development 4, Yokohama, Japan. 38 p.

Kartodihardjo, H. 1999. Belenggu IMF \& World Bank: Hambatan Struktural Pembaharuan Kebijakan Pembangunan Kehutanan di Indonesia. Pustaka LATIN, Bogor.

Landres, P.B. 1992. Ecological indicators: Panacea or liability? In: McKenzie, D.H., Hyatt, D.E. and McDonald, J.E. (eds) Ecological Indicators, Volume: 2, 1295-1319. Elsevier Applied Science, London.

Liang, T.Y. 1994. The basic entity model: a fundamental theoretical model of information and information processing. Information and Management 30: 647-61.

Muhtaman, D.R., Siregar, C.A., and Hopmans, P. 2000. Criteria and indicators for sustainable plantation forestry in Indonesia. CIFOR, Bogor, Indonesia. 72p. 
Nambiar, E.K.S. 1996. Sustained productivity of forests is a continuing challenge to soil science. Soil Science Society of America Journal 60: 1629-1642

Nambiar, E.K.S. and Brown, Alan G. 1997. Management of soil, nutrients and water in tropical plantation forests. ACIAR Monograph No. 43. ACIAR-CSIRO-CIFOR, Canberra, Australia. $571 \mathrm{p}$.

Potter, L. and Lee, J. 1988. Tree planting in Indonesia: trends, impacts and directions. CIFOR Occasional Paper No. 18. CIFOR, Bogor, Indonesia. 75p.

Prabhu, R., Colfer, C.J.P., Venkateswarlu, P., Tan, L.C., Soekmadi, R., and Wollenberg, E. 1996. Testing criteria and indicators for the sustainable management of forests: Phase I final report. CIFOR Special Publication. CIFOR, Bogor, Indonesia.

Purnadjaja, Tan Kee Chong, Manurung, E.G..T., Supriyono, H., Makinuddin , Widyastuti, S.M., and Sutarahardja, S. 1997a. Testing criteria and indicators of sustainable management of plantation forests. Field test Team 1 report. CIFOR, Bogor, Indonesia.

Purnadjaja, Nuhamara, S.T., Astana, S., Saleh, M.B., Agus, C., and Rahayu, S. 1997b. Testing criteria and indicators of sustainable management of plantation forests. Field tes Team 2 report. CIFOR, Bogor, Indonesia.

Purnadjaja, Indrawan, A., Siregar, C.A., Muhtaman, D.R., Purwanto, S.A., Warsito, S.P. and Darma, I.G.K.T. 1998. Testing criteria and indicators of sustainable management of plantation forests. Field test Team 3 report. CIFOR, Bogor, Indonesia.

SmartWood. 2001. Generic Guidelines for Assessing Forest Management. SmartWood. 
van Bueren, E.M.L. and Blom, E.M. 1997. Hierarchical framework for the formulation of sustainable forest management standards - Principles, criteria, and indicators. The Tropenbos Foundation, Leiden, The Netherlands. 82p.

Wollenberg, E. and Colfer, C. 1997. Social sustainability. In: Borrini-Feyerabend, G. and Buchan, D. (eds.) Beyond fences: seeking social sustainability in conservation. Volume 2: A resource book, 115-117. IUCN, Gland, Switzerland. 


\section{Further Reading}

Awang, K. and Taylor, D. (eds.) 1993. Acacia mangium, growing and utilization. Monograph, Winrock International and FAO, Bangkok, Thailand. 258p.

Bhopal-India Process. 1999. Bhopal India Process for sustainable management of Indian forests. Indian Institute of Forest Management, Bhopal, Madhya Pradesh, India.

CIFOR. 1999. The criteria and indicators toolbox series. CIFOR, Bogor, Indonesia.

Dudley, N. 1997. Guidelines for timber plantations, environmental, social and cultural issues relating to commercial afforestation (draft). A report for WWF and IUCN. Equilibrium, UK. $73 p$.

Forest Stewardship Council (FSC). 1999. Principles and crietria for forest stewardship. http://www.fscoax.org (January 1999).

International Tropical Timber Organization (ITTO). 1993. ITTO Guidelines for the establishment and sutainable management of planted tropical forests. ITTO Policy Development 4, Yokohama, Japan. 38p.

Ministry of Forestry and Estate Crops (MoFEC). 1998. Rearrangement of large scale land ownership and forest utlization in connection with the resource benefit redistribution (in Indonesia). Jakarta.

Muhtaman, D.R., Siregar, C.A. and Hopmans, P. 2000. Criteria and indicators for sustainable plantation forestry in Indonesia. CIFOR, Bogor, Indonesia. 72p.

Nambiar, E.K.S. and Brown, Alan G. 1997. Management of soil, nutrients and water in tropical plantation forests. ACIAR Monograph No. 43. ACIAR-CSIRO-CIFOR, Canberra, Australia.

Potter, L. and Lee, J. 1988. Tree planting in Indonesia: trends, impacts and directions. CIFOR Occasional Paper No. 18. CIFOR, Bogor, Indonesia. 75p. 
Prabhu, R., Colfer, C.J.P. and Dudley, R.G. 1999. Guidelines for developing, testing and selecting criteria and indicators for sustainable forest management. The Criteria Indicators Toolbox Series No. 1. CIFOR, Bogor, Indonesia. 186p.

Prabhu, R., Colfer, C.J.P., Venkateswarlu, P., Lay Cheng Tan, Rinekso Soekmadi and Wollenberg, E. 1996. Testing criteria and indicators for the sustainable management of plantation forests: Phase 1. Final Report. CIFOR Special Publication. CIFOR, Bogor, Indonesia. 217p.

Purnadjaja, Tan Kee Chong, Manurung, E.G..T., Supriyono, H., Makinuddin , Widyastuti, S.M., and Sutarahardja, S. 1997a. Testing criteria and indicators of sustainable management of plantation forests. Field test Team 1 report. CIFOR, Bogor, Indonesia.

Purnadjaja, Nuhamara, S.T., Astana, S., Saleh, M.B., Agus, C., and Rahayu, S. 1997b. Testing criteria and indicators of sustainable management of plantation forests. Field tes Team 2 report. CIFOR, Bogor, Indonesia.

Purnadjaja, Indrawan, A., Siregar, C.A., Muhtaman, D.R., Purwanto, S.A., Warsito, S.P. and Darma, I.G.K.T. 1998. Testing criteria and indicators of sustainable management of plantation forests. Field test Team 3 report. CIFOR, Bogor, Indonesia.

Sankar, C., Anil, P.C. and Amruth, M. 2000. Criteria and Indicators for Sustainable Plantation Forestry in India. CIFOR, Bogor, Indonesia. $72 \mathrm{p}$.

van Bueren, E.M.L. and Blom, E.M. 1997. Hierachical framework for the formulation of sutainable forest management standards - Principles, criteria, and indicators. The Tropenbos Foundation, Leiden, The Netherlands. 82p.

Wijewardena, D., Caswell, S.J. and Palmberg-Herche, C. 1997. Criteria and indicators for sustainable forest management. Proceeding of the XI Forest Congress 13-22 October, Antalya, Turkey.

Wollenberg, E. and Colfer, C. 1997 Social sustainability. In: Borrini-Feyerabend, G. and Buchan, D. (eds.) Beyond fences: seeking social sustainability in conservation. Volume 2:A resource book, 115-117. IUCN, Gland, Switzerland. 
Annex 1. The initial set of Social Criteria and Indicators, which were evaluated and used as the basis for the workshop and the development of the C\&I (cf. Table 1 for the revised set)

\section{Principle}

\section{Criterion}

Indicators

\section{Human well-being is enhanced}

\section{Stakeholders tenure and land use rights secured}

Conflicts are minimal or settled

Tenures are well defined and upheld

Long term tenure or agreement to land is guaranteed and its customary rights are respected

Opportunities exist for local community to continue socio-economic activities within the forest concession area

Opportunities exist for local community to get compensating rewards for loss of land and other resources

\section{Stakeholders participate in forest management}

Fair and effective mechanism for conflict resolution exist

Local community understand and are involved in the process of forest management activities

Management understand and consider the local knowledge in the forest management activities

Effective mechanism exist for two-way communication and consultation Professional staff for community development is available and fully supported by the management

Socio-economic performance for local community is enhanced

People's income have increased in real term since the establishment of forest plantation 


\section{Annex 1. Continued}

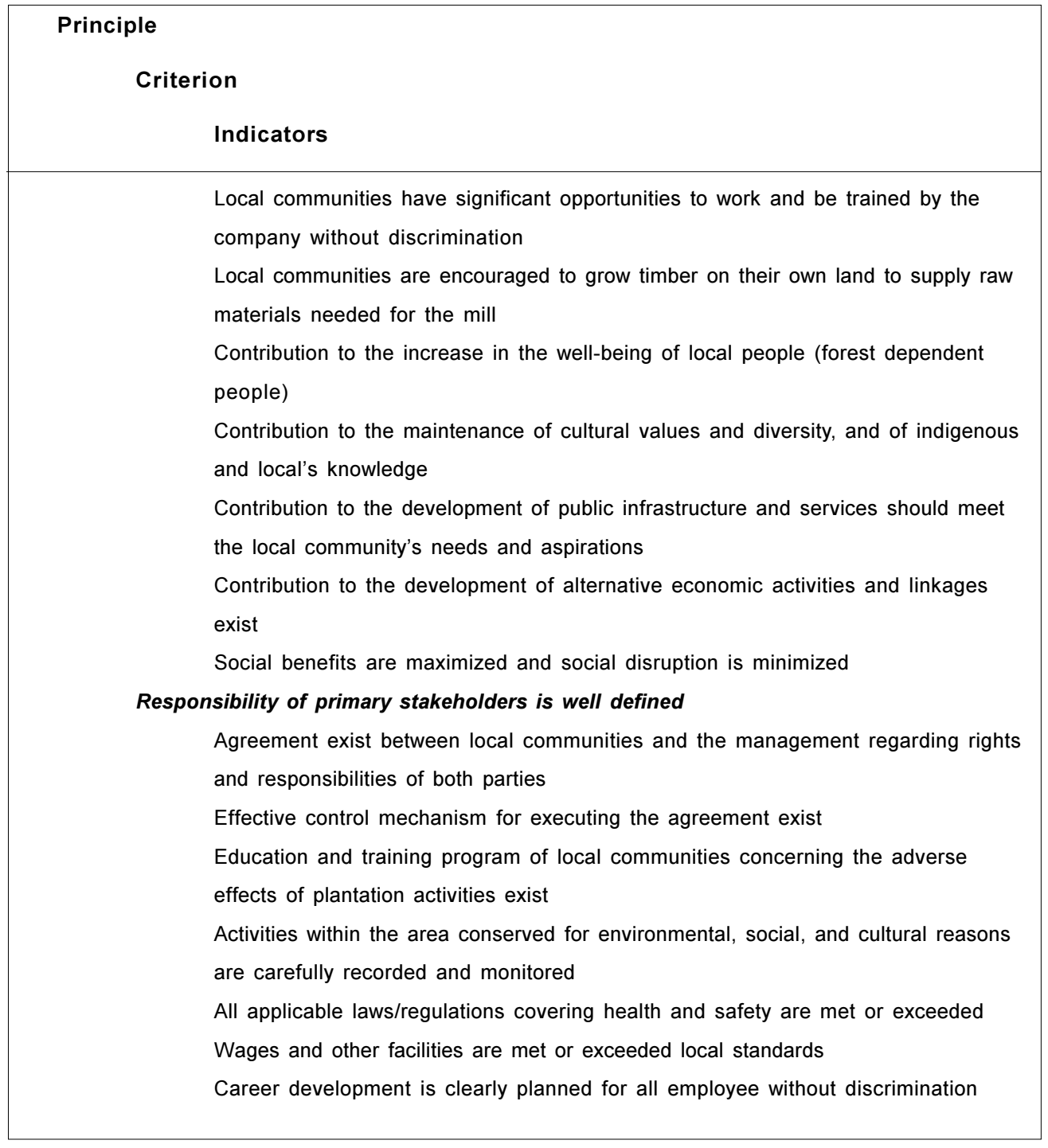


Annex 2. The initial set of Management Criteria and Indicators, which were evaluated and used as the basis for the workshop (cf. Table $2 \mathrm{a}, 2 \mathrm{~b}$ and $2 \mathrm{c}$ for the revised set)

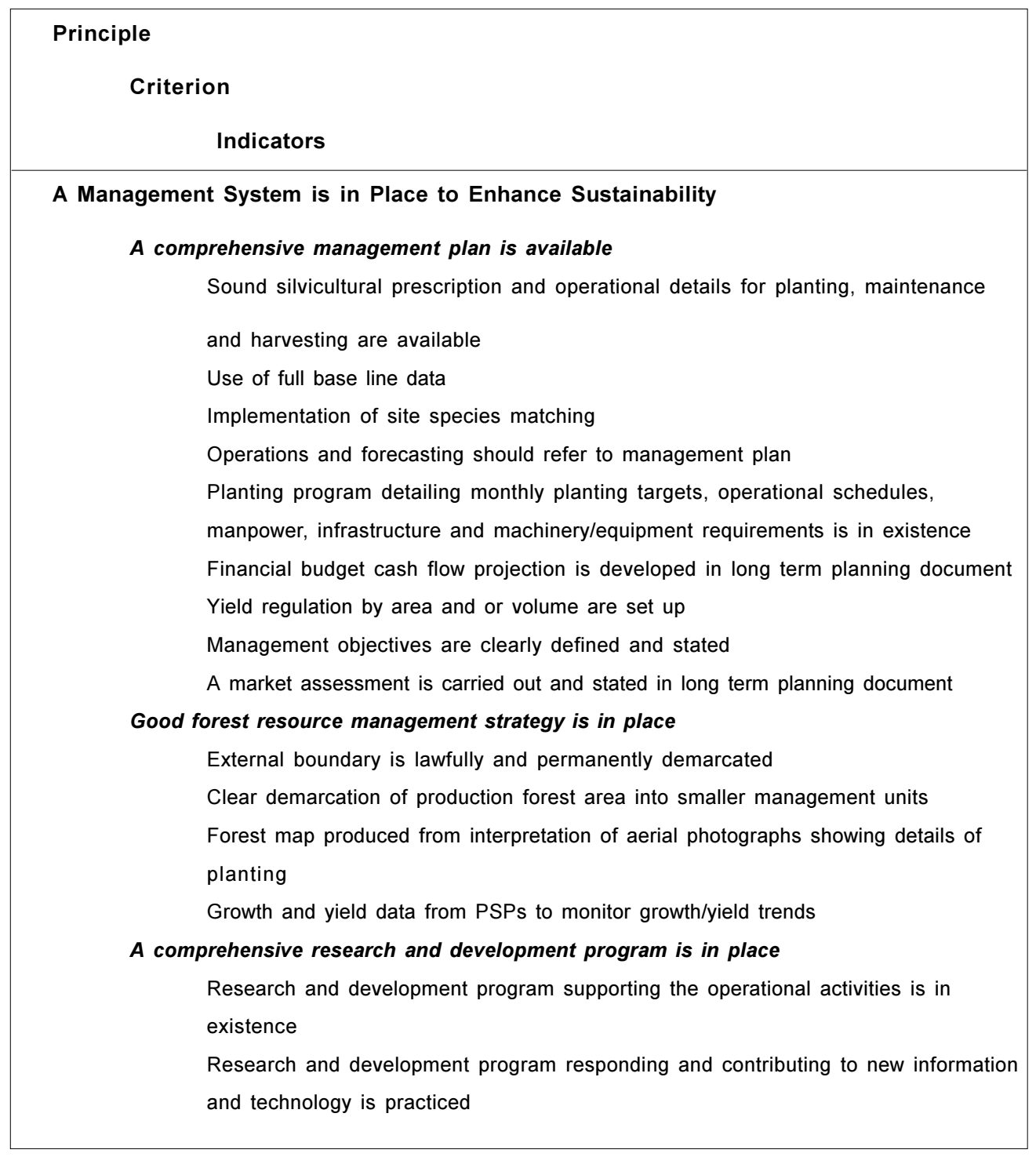




\section{Annex 2. Continued}

\section{Principle}

\section{Criterion}

\section{Indicators}

There is sustained and adequate funding for running the operations

Liquidity of cash flow to support infrastructure development, acquisition of machinery and equipment and to meet day to day running of the operation

\section{Effective monitoring and control system audits conformity of Management plan}

Documentation and records of all forest management activities are kept for monitoring purposes

Periodical forest inventory system exist

Standard of planting and tending

\section{Forest maintenance and protection program are implemented}

Operational system of forest fire prevention and suppression are implemented Well defined integrated pest and disease management program are practiced Operational system of forest security is implemented

\section{Professional and dedicated human resources are enhanced}

Adequate human resources at all levels of management

Human resources development is implemented

Clear organization structure with job description is developed

Human resources welfare program exists

Operational guidelines of safety procedures for handling chemicals, vehicles, and machinery are available 
Annex 3. The initial set of Ecological Criteria and Indicators, which were evaluated and used as the basis for the workshop (cf. Table 3 for the revised set)

\begin{tabular}{|l}
\hline Principle \\
Criterion \\
Indicators \\
Ecosystem function is maintained or improved \\
Structure and ecosystem function is maintained \\
Judicious use of chemical for pest, disease, and weed management, and fertilizer \\
Protected area and conservation area are maintained \\
Endangered flora and fauna are protected \\
Micro climatic change and hydrology function are improved \\
Stand growth quality is satisfaction \\
Soil and water resources are maintained or improved \\
Soil physical and chemical properties are maintained \\
Water quality is maintained \\
Adversely environmental influence is minimized \\
Fire prevention is in force \\
Mix-cropping is preferable compared to mono-culturing
\end{tabular}




\section{Code of Practice for Industrial Tree Plantation Development in the Tropics}
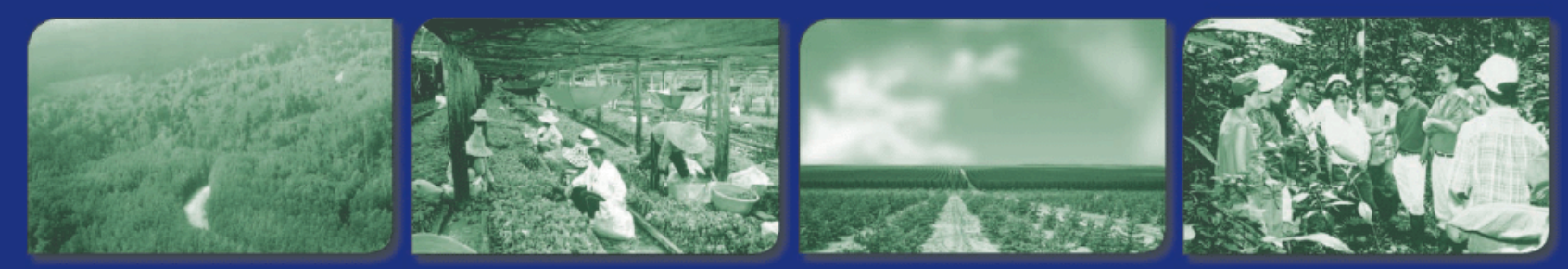

Grahame Applegate and Dan Raymond 


\title{
Code of Practice for Industrial Tree Plantation Development in the Tropics
}

\author{
Grahame Applegate \\ Dan Raymond
}

As part of the continuing search for practical ways to apply C\&l to development, this document is offered to directly provide a link between C\&I and a code of practice for sustainable development of largescale tropical industrial plantations. Adoption of C\&I requires consultation but must be based on practice - this book offers a framework for field testing the results of which should inform progressive improvement of both the criteria and the codes of practice. For this reason, CIFOR invites all users of this text to provide feedback, including suggestions for improvement, using the following addresses:

Grahame Applegate: <g.applegate@cgiar.org> Fax: (62-251) 622100

John Poulsen: $\quad$ <j.poulsen@cgiar.org> Fax: (62-251) 622100 


\section{Table of Contents}

Abbreviations vii

Acknowledgements viii

Foreword ix

Mission Statement xi

1. Introduction 1

1.1 Growing International Awareness and Initiatives $\quad 1$

1.2 Purpose 3

1.3 Stakeholder Roles 3

2. Plantation Planning 6

2.1 Planning Levels $\quad 6$

2.2 Requirements for Effective Planning 9

3. Landscape Level Planning 12

$\begin{array}{ll}3.1 \text { Biophysical } & 12\end{array}$

$\begin{array}{ll}3.2 \text { Cadastral Data } & 13\end{array}$

$\begin{array}{ll}3.3 \text { Socio-Economic Data } & 13\end{array}$

3.4 Environmental/Biodiversity 15

3.5 Exclusion Zones for Landscape Level Planning 17

4. Stand Level Planning 20

5. Roading and Drainage 21

$\begin{array}{ll}5.1 \text { Road Classification } & 21\end{array}$

$\begin{array}{ll}5.2 \text { Road Design } & 22\end{array}$

5.3 Road and Acces Track Construction 25

6. Road Watercourse Crossings 32

6.1 Types of Crossings and Uses $\quad 32$

6.2 Construction of Watercourse Crossings 33

$\begin{array}{ll}7 . & \text { Quarries } \\ \end{array}$

$\begin{array}{ll}7.1 \text { Sources of Quarry Material } & 37\end{array}$

$\begin{array}{ll}7.2 \text { Quarry Management } & 38\end{array}$

$\begin{array}{ll}7.3 \text { Quarry Rehabilitation } & 38\end{array}$ 
8. Plantation Development at Stand Level 39

$\begin{array}{ll}8.1 \text { Planning } & 39\end{array}$

$\begin{array}{ll}\text { 8.2 Pre-harvest Activity } & 39\end{array}$

$\begin{array}{ll}8.3 \text { Log Landings } & 40\end{array}$

8.4 Planning Skid Trails $\quad 41$

8.5 Harvesting Operations $\quad 42$

8.6 Log Cross-cutting and Debranching $\quad 44$

8.7 Weather Limitations on Harvesting 48

8.8 Monitoring and Evaluation of Development Activity 48

9. Log Pond and Wharf 51

9.1 Location $\quad 51$

9.2 Timing of Construction $\quad 52$

9.3 Design $\quad 52$

9.4 Maintenance $\quad 53$

9.5 Decommissioning/Rehabilitation $\quad 53$

10. Plantation Establishment 54

10.1 Site Preparation $\quad 54$

10.2 Site Preparation on Peat Soils $\quad 58$

$\begin{array}{ll}10.3 \text { Planting } & 58\end{array}$

10.4 Herbicide and Pesticide Application $\quad 59$

$\begin{array}{ll}10.5 \text { Fertiliser Application } & 60\end{array}$

10.6 Alternatives to Herbicide/Pesticide/Fertiliser 61

11. Employee Conditions 62

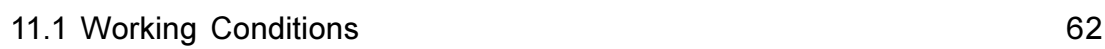

$\begin{array}{ll}11.2 \text { Personnel Safety Requirements } & 63\end{array}$

11.3 Equipment Safety Requirements $\quad 64$ 
$\begin{array}{ll}\text { 12. Fire Management } & 67\end{array}$

$\begin{array}{ll}12.1 \text { Education } & 67\end{array}$

$\begin{array}{ll}12.2 \text { Preparation } & 67\end{array}$

$\begin{array}{ll}12.3 \text { Fire Suppression } & 68\end{array}$

12.4 Chainsaws and Machines $\quad 69$

13. Harvesting Equipment Maintenance 70

$\begin{array}{ll}\text { 13.1 Moving Equipment } & 70\end{array}$

$\begin{array}{ll}\text { 13.2 Workshop Facilities } & 70\end{array}$

$\begin{array}{ll}\text { 13.3 Toxic Waste } & 70\end{array}$

$\begin{array}{ll}\text { 13.4 Main Fuel and Oil Storage } & 71\end{array}$

$\begin{array}{ll}13.5 \text { Field Servicing and Maintenance } & 72\end{array}$

13.6 Refuse Disposal $\quad 72$

14. Camp Hygiene $\quad 73$

$\begin{array}{ll}\text { 14.1 Camp Design Plans } & 73\end{array}$

$\begin{array}{ll}14.2 \text { Water Supply } & 73\end{array}$

$\begin{array}{ll}14.3 \text { Liquid Waste Disposal } & 73\end{array}$

$\begin{array}{ll}14.4 \text { Non Liquid Waste Disposal } & 74\end{array}$

$\begin{array}{ll}14.5 \text { Water Ponding } & 74\end{array}$

$\begin{array}{ll}\text { 14.6 Additional Facilities } & 74\end{array}$

15. Competency Based Training System for Plantations 75

$\begin{array}{ll}\text { 15.1 Minimum Competency Standards } & 75\end{array}$

$\begin{array}{ll}\text { Glossary } & 78\end{array}$

$\begin{array}{lr}\text { References } & 86\end{array}$ 


\section{Figures}

Figure 2.1 Example of Landscape Level Planning Map 8

$\begin{array}{lll}\text { Figure 3.1 Procedure for Typing Watercourses } & 19\end{array}$

Figure 5.1 Road Location and Drainage 23

Figure 5.2 Major and Minor Road Construction 27

$\begin{array}{lll}\text { Figure } 5.3 \text { Cross-Drain System } & 31\end{array}$

$\begin{array}{lll}\text { Figure 6.1 Culvert Construction } & 35\end{array}$

\section{Table}

Table 2.1 Information Required by Planners at the Landscape $\begin{array}{ll}\text { and Standlevels } & 10\end{array}$

$\begin{array}{lll}\text { Table 3.1 Buffer Area Protection Guidelines } & 18\end{array}$

$\begin{array}{lll}\text { Table } 8.1 & \text { Evaluation form } & 49\end{array}$

Table 10.1 Summary of Site Preparation Systems 56

Table 11.1 Guide to Protective Clothing 66 


\section{Abbreviations}

$\begin{array}{ll}\text { APRIL } & \text { Asia Pacific Resources International (Holding) Ltd. } \\ \text { C\&I } & \text { Criteria and Indicators } \\ \text { CIFOR } & \text { Center for International Forestry Research } \\ \text { cm } & \text { centimetres } \\ \text { Code } & \text { Code of Practice for Industrial Tree Plantation Development in the Tropics } \\ \text { FAO } & \text { Food and Agriculture Organization } \\ \text { FOPS } & \text { Falling Object Protection Structure } \\ \text { FSC } & \text { Forest Stewardship Council } \\ \text { GIS } & \text { Geographic Information System } \\ \text { GPS } & \text { Global Positioning System } \\ \text { IFF } & \text { Intergovernmental Forum on Forests } \\ \text { ILO } & \text { International Labour Organization } \\ \text { IPB } & \text { Institut Pertanian Bogor (Bogor Agriculture Institute) } \\ \text { ITTO } & \text { International Tropical Timber Organization } \\ \text { LATIN } & \text { Lembaga Alam Tropik Indonesia } \\ \text { LEI } & \text { Lembaga Ekolabel Indonesia (Indonesian Ecolabelling Institute) } \\ \text { m } & \text { metres } \\ \text { mm } & \text { millimetres } \\ \text { ROPS } & \text { Roll Over Protection Structure } \\ \text { SFM } & \text { Sustainable Forest Management } \\ \text { UNCED } & \text { United Nations Conference on Environment and Development } \\ \text { UNCSD } & \text { United nations Commission on Sustainable Development } \\ \end{array}$




\section{Acknowledgements}

The contributions of the following are gratefully acknowledged:

- $\quad$ The APRIL Group and specifically staff at PT Riau Andalan Pulp and Paper for funding and hosting a workshop in Sumatra at which this document was refined.

- $\quad$ URS Forestry for consulting services.

- $\quad$ CIFOR for co-ordinating the development of this Code, funding various activities and logistical support.

- Much of the information for this document was drawn from the Asia-Pacific Forestry Commission's Code of Practice for Forest Harvesting in Asia-Pacific and the Code of Conduct for Logging of Indigenous Forests in Selected South Pacific Countries. 


\section{Foreword}

Over the last ten years there has been an increasing emphasis on development of industrial tree plantations for wood fibre. While the end products from these plantations may be different, the principles of development and establishment to account for the production, social, environmental and biodiversity aspects are the same.

This Code of Practice for Industrial Tree Plantation Development in the Tropics (Code) has been developed by the Center for International Forestry Research (CIFOR) and partners including the Bogor Agricultural University (IPB), the Indonesian Tropical Institute (LATIN), the Ecolabelling Institute of Indonesia (LEI) and PT Riau Andalan Pulp and Paper (RAPP) ${ }^{1}$. This document provides details on principles and minimum standards relating to improved plantation development and establishment. The acceptance of this Code will also be a component of a plantation manager's commitment to sustainable forest management (SFM). The principles contained within this document can provide a model for the tropics, which could be adopted to meet plantation development requirements in specific countries with appropriate modifications to reflect national circumstances.

CIFOR and its partners have also developed Criteria and Indicators (C\&I) for Plantation Development. Criteria and indicators can provide a benchmark for large plantation managers to assess progress towards SFM within their forest estate. The Code is designed to complement the C\&I for Plantation Development by providing a minimum set of standards for plantation development and many of the verifiers for the C\&I. The two documents have therefore been developed simultaneously to simplify assessment of compliance and to highlight their complementarity.

Through current changes to forestry policies and/or environmental legislation, many tropical countries have provided strong support for sustainable forest management. The ability of countries to implement sustainable forest management in industrial tree plantations will be enhanced by the adoption of this Code and compliance with appropriate C\&I for Plantation Development.

\footnotetext{
${ }^{1}$ RAPP is part of the Asia Pacific Resources International (Holding) Ltd. (APRIL Group)
} 


\section{Vision}

To be recognised as responsible and progressive managers of our plantations

for present and future generations

\section{Mission}

To manage plantations

to maximise financial, environmental

and community benefits

\section{Values}

Community benefit environmental

protection economic return 


\section{Introduction}

The Code of Practice for Industrial Tree Plantation Development in the Tropics (Code) has been developed to provide minimum standards for large scale timber plantation development in the tropics. It focuses specifically on development of plantation estates involving both conversion of tropical forest to plantations and conversion of degraded land often dominated by Imperata cylindrica. It does not address on going plantation silvicultural management practices.

The Code of Practice for Industrial Tree Plantation Development in the Tropics uses two levels to define management of plantation development. These are:

- Landscape Level - The entire area comprising the plantation estate

- Stand Level - Individual plantation units within the estate which comprise a single contiguous age class and planting of the same species or taxa.

Implementation of the Code does not ensure sustainable forest management (SFM) or fulfil criteria for certification of wood products. However, implementation of the Code will demonstrate a commitment to good environmental practices.

\subsection{Growing International Awareness and Initiatives}

The world faces an expanding population and with this an increasing demand for wood based products and fuelwood. Increasingly, most of this demand will be met by large-scale plantation development. World wide, approximately 115 million hectares of forest plantation have been established (ABARE - Jaakko Pöyry 1999). Sixty-two percent of this is in the traditional wood producing countries of Europe, Russia, and North and South America. In the last decade, there has been a rapid expansion of the plantation area with in subtropical regions of Asia, Africa and South America. Estimates indicate that the plantation area suitable for commercial wood production is 11.2 million hectares in Asia (ABARE - Jaakko Pöyry 1999). As native forests continue to be depleted, areas in Asia and elsewhere in the tropics will maintain their expansion of timber plantations for industrial purposes to provide product for the expanding population in the region. 
The rapid expansion of plantations creates concerns for capacity to maintain environmental values and community needs while producing timber products demanded by society. This has become apparent with the number of international agreements which impact in some way on plantation development. These include:

- The United Nations Conference on Environment and Development (UNCED), held in Rio de Janeiro in 1992, which provided a forum for the international community to focus on the environment and make commitments to the sustainable management of the world's forests.

- The Intergovernmental Panel on Forests was established in 1994 by the UN. This panel developed on agreed set of more than 150 proposals for action the management, conservation and sustainable development of all types of forests.

- In 1997, the Intergovernmental Forum on Forests (IFF) was established by the United Nations Commission on Sustainable Development (UNCSD). The IFF facilitated global discussion on activities and recommendations for SFM involving international organisations, national governments, non-government organisations, and the private sector. One particular recommendation of the IFF was a call for the development of voluntary codes of practice for forest management activities including timber harvesting.

- ITTO adopted a multifaceted approach to SFM, through the introduction of the "Year 2000 Objective" as part of its program to promote conservation and sustainable management of tropical forests. This objective called for all internationally traded tropical timber to be sourced from sustainably managed forests by the year 2000 .

- Criteria and indicators (C\&I) have been developed in various regions around the world. The world's temperate and boreal forests are covered by the Helsinki Process and the Montreal Process. Apart from the C\&I developed by ITTO, C\&I were developed for other tropical forests as part of the Tarapoto Proposal and the Central American Process.

- The development of international standards for environmental management systems and environmental auditing, certification and labelling through organisations such as the International Standards Organization (ISO), Forest Stewardship Council (FSC), and other international and national organisations.

- Regional, National and Provincial codes of practice have been developed for many areas and forest types around the world. 


\subsection{Purpose}

The purpose of the Code of Practice for Industrial Tree Plantation Development in the Tropics is to provide:

- an expression of plantation managers commitment to SFM;

- a set of minimum standards for improved practices for plantations;

- capacity to fulfil the criteria and indicators for improved management of plantations;

- support for the protection of sites of cultural, historical, archaeological, geomorphological, biological and spiritual significance;

- guidelines for resource areas for local communities;

- guidelines for biodiversity conservation measures for flora and fauna;

- support for promoting plantation productivity;

- support for improvement of the health and safety of forest workers;

- support for maximum economic return from plantations; and

- support for an equitable distribution of benefits from the forest.

In itself, the Code does not ensure sustainable management, however, compliance with its guidelines will move plantation development operations closer to the achievement of SFM.

\subsection{Stakeholder Roles}

\subsubsection{Issues for Stakeholders}

A number of issues need to be considered by the stakeholders for the successful implementation of the Code. Two of the most important issues are:

- plantation development must comply with the relevant land-use planning framework; and

- plantation development must be planned to allow for financial, social biodiversity and other environmental needs. 


\subsubsection{Roles of Stakeholders}

\section{Government}

- Provide land-use policies and the appropriate legislative and infrastructural framework to promote sustainable plantation development and maintenance.

- To promote mechanisms for appropriate land-use policy implementation, education and training, and encouragement for the ecologically and socially sustainable use and management of plantations.

- Monitor and evaluate harvesting operations for compliance with the Code.

\section{Plantation owners}

- Comply with land-use planning guidelines and the Code.

- Maintain the capacity of the plantation resource to supply a viable financial return on investment while providing other community and environmental benefits.

- Protect neighbouring and downstream resources.

- Implement effective and safe operations.

- Train and employ local community members in order to increase skill levels that can be used in the future.

\section{Communities}

- Assist in educating and training the community members in protection of the plantation resource.

- Employment and income generation.

- Identify multiple use needs of community members.

- Assist in planning for and arranging the equitable sharing of benefits from plantations and associated activities.

- Assist with monitoring plantation management compliance with the Code.

- Provide indigenous knowledge related to the plantation. 


\section{Non-Government Organisations}

- Education and promotion on the benefits of plantations to communities.

- Promotion of sound principles and practices for plantations (including agroforestry) through the Code of Practice for Industrial Tree Plantation Development in the Tropics.

- Assist with ensuring Code compliance, monitoring and auditing procedures. 


\section{Plantation Planning}

\section{OBJECTIVES}

- To ensure sustainable development of plantations meeting production, social and biological requirements.

\subsection{Planning Levels}

Three planning levels will affect the development of plantation estates both for small and large holders. These are :

1. Land-use planning by Government bodies;

2. Landscape level planning by an estate/concession holder; and

3. Stand level planning by an estate/concession holder.

Initially land-use planning will be carried out by Government at one or more of the National, provincial/regional or district levels. Typically, land-use planning will designate areas for:

- production forests;

- National Parks/protection forests/conservation forests;

- conversion forests for agriculture or plantation development;

- agricultural production areas or other uses eg. mining;

- urban areas;

- infrastructure; and

- community managed forests.

Development of plantations should occur only in areas designated for plantation development under official land-use planning guidelines. 
Following the designation of areas for industrial tree plantation development, planning for plantations will occur on 2 levels:

- Landscape Level; and

- Stand Level.

The Landscape Level refers to the entire concession area. For a large landowner the concession area may be contiguous or non-contiguous tracts of land covering hundreds of thousands of hectares, including existing and planned road networks in existing plantations, areas designated for conversion to plantation, conservation areas, villages, streams, etc. Prior to commencing any activity within this area, satisfactory Landscape Level plans must be developed.

Stand Level planning refers to individual plantation units. These are usually a single contiguous area of land with trees of the same age class, planted with the same species and are commonly referred to as stands, compartments, blocks or management units. Generally their size is less than one hundred hectares. Prior to commencing development of any Stand, a Stand Development Plan complying with the Landscape Level Plan must be prepared and demarcated on the ground.

An example of a Landscape Level Plan showing the individual Stands is shown in Figure 2.1. 


\subsection{Requirements for Effective Planning}

An integrated approach to forest planning requires consideration of three areas crucial to the implementation of sustainable development. These are:

- Biological (includes silvicultural and environmental).

- Market (includes economic and financial).

- Socio-economic (includes social issues, legal framework and institutions).

If the requirements of each of these areas are not adequately determined and provided for then sustainable development will not be achieved and the long term success of any plantation development project is unlikely.

To determine the requirements for each of these areas, planning is carried out at the Landscape and Stand levels. Forest planners require accurate bio-physical, cadastral, socioeconomic and environmental/biodiversity data on the area under consideration. Required data is summarised in Table 2.1 . 
Table 2.1 Information Required by Planners at the Landscape and Standlevels

\begin{tabular}{|c|c|c|}
\hline Planning Information & $\begin{array}{c}\text { Landscape Level } \\
\text { (Maps of more than } 1: 25,000 \text { scale) }\end{array}$ & $\begin{array}{c}\text { Stand Level } \\
\text { (Maps of less than 1:5,000 scale) }\end{array}$ \\
\hline \multirow{8}{*}{ Bio-physical } & Contours/Slope classes & Contours/Slope classes \\
\hline & Soil classes & Soil classes \\
\hline & Drainage patterns & Drainage patterns \\
\hline & Forest type and distribution & Plantation boundaries \\
\hline & Site capability & Site capability \\
\hline & Climatic data & Site suitability \\
\hline & Existing infrastructure & Road networks \\
\hline & Site suitability & \\
\hline \multirow[t]{3}{*}{ Cadastral } & Cadastral boundaries & Cadastral boundaries \\
\hline & (land-use/ownership) & (land-use/ownership) \\
\hline & $\begin{array}{l}\text { Land-use zoning (Conservation, } \\
\text { conversion, etc.) }\end{array}$ & \\
\hline \multirow[t]{4}{*}{ Socio-economic } & $\begin{array}{l}\text { Existing land-use patterns and future } \\
\text { requirements }\end{array}$ & \\
\hline & Ethnic groups and dynamics & \\
\hline & Predicted growth & \\
\hline & Livelihood income patterns & \\
\hline \multirow[t]{4}{*}{ Environmental/Biodiversity } & $\begin{array}{l}\text { Remnant forest areas, shape and } \\
\text { fragmentation level }\end{array}$ & $\begin{array}{l}\text { Remnant forest patches within } \\
\text { planted areas }\end{array}$ \\
\hline & Species biodiversity & \\
\hline & Indicator species requirements & \\
\hline & Biodiversity usage & \\
\hline
\end{tabular}


Most of this information can be displayed as maps, which should be accurate, and at a scale that provides sufficient detail for the purposes required. Most organisations now maintain Geographic Information Systems (GIS) which allow development of maps showing this information as required and at the desired scale. If no GIS system is maintained then a paper mapping system must be used. This system should also be linked with the Stand Register which contains records of all management activity within each Stand. 


\section{Landscape Level Planning}

\section{OBJECTIVES}

- To schedule plantation development activity.

- To ensure stakeholder participation in the planning process.

- To identify and protect areas to be excluded from harvesting for environmental/biodiversity and community needs.

- To ensure that all Landscape Level Planning is completed prior to commencement of clearing for planted area development.

The process of developing a Landscape Level Plan is a major undertaking and requires balancing of a range of requirements. The Landscape Level Plan is broad-scale and longterm. As such it is subject to change during the period of its implementation, but it must be completed prior to commencement of forest or land use conversion.

Following is an outline of the process required to develop a Landscape Level Plan. An indicative ordered list of activities is provided.

\subsection{Biophysical}

Much of the biophysical data required to carry out landscape level planning should already be available in map form or on existing GIS systems. This data includes:

- Contours/Slope classes

- Soil classes

- Drainage patterns

- Forest type and distribution

- Site capability 
- Climatic data

- Existing infrastructure

This data must be collated and any information not available collected. The collection process may include field data collection from surveys, satellite data or airphoto interpretation. Once collated and mapped this information becomes the basis for the rest of the planning process.

\subsection{Cadastral Data}

Cadastral data takes two forms. The first is the known land-use planning areas and the second is land ownership or tenure boundaries. This information should be overlain with the biophysical data and used in the rest of the planning process.

\subsection{Socio-Economic Data}

Within any area zoned for plantation development provision should be made for community requirements. These need to take the form of access to land for, traditional use, agriculture, employment, water quality and other uses.

A permanent Community Development Section should be established by the concessionaire and funded to ensure that these socio-economic needs are adequately addressed.

\subsubsection{Security of tenure and land-use}

The following process must be undertaken for each identified community within and bordering the concession area:

- A permanent public participatory forum should be established including representatives from concessionaires and the community with the power to make decisions on landuse. The forum brings the socio-economic needs of the community and the requirements of the concessionaire together. 
- At the completion of the participatory planning process a land-use agreement is developed and signed by stakeholders in the forum. The land-use agreement shows land allocation, size and is delineated on a GIS, or map and then permanently demarcated on the ground with community representatives.

- An agreement allowing community access to the forest for products and services is signed by the forum members.

- Where appropriate, a letter of compensation should be provided by the concessionaire and signed by the forum members.

\subsubsection{Stakeholder involvement in plantation planning, management and monitoring}

- A permanent public participatory forum ${ }^{2}$ should be established including representatives from concessionaires and the community with the power to make decisions involving conflict involving the community and the concessionaire.

- Land-use information must be provided to the forum in a user friendly format by the concessionaire and by the community. This includes identification and protection of cultural sites and support of cultural activities.

- The biophysical planning map will be used in the land-use decision making process to delineate the physical needs of the community in terms of resource areas.

- The Community Development Section to be developed by the concessionaire with trained officers and funded to ensure that socio-economic needs of the community impacted upon by the plantation development are adequately addressed.

\subsubsection{Economics for local communities}

- Preferential share holdings may be issued for co-operatives.

- Concessionaire to maximise the opportunity for local employment and income generation in plantation development activities.

- If the concessionaire has a processing mill, it should provide support to out grower schemes as part of the community development program.

\footnotetext{
${ }^{2}$ This may be effective if community groups are coordinated by NGOs prior to meetings.
} 
- The forum allows the community to direct the development of infrastructure and services.

- Concessionaires to provide training and support for income generation e.g. improved farming practices, marketing/business development.

- Concessionaires to provide formal and vocational training as agreed by the forum.

\subsubsection{Responsibility of stakeholders}

- A Memorandum of Understanding detailing the rights and responsibilities of the concessionaire and the community ratified by the forum.

- Concessionaire meets all legal obligations in employing community members as specified on employment contracts.

\subsection{Environmental/Biodiversity}

Maintenance of biodiversity is of primary importance in flora and fauna conservation. While it is recognised that the primary responsibility for conservation is at the land-use planning level, there is potential to conserve some biodiversity within the plantations. Conservation of biodiversity is dependent on the maintenance of habitat, enhancing opportunities for recolonisation of cut-over areas and by linking exclusion zones to allow genetic interchange. This may be achieved in the following ways:

- Setting aside natural forest reserves within production areas large enough to maintain viable populations of plants and animals particularly where rare or endangered.

- Retaining areas of unlogged forest to maintain habitat diversity. These areas should connect patches of forest as corridors which will not be logged.

- Retaining habitat trees in production areas where appropriate for wildlife.

- Representation of forest types to be adequately reserved in conservation forests.

It is suggested that biodiversity protection is achieved through the identification of indicator species by a skilled biologist. An indicator species is a plant or animal species which is 
typical in its habitat requirements of a range of other species and about which knowledge exists of its habitat requirements. Requirements for provision of a viable habit for this species should ensure suitable habit requirements for other species. This can then be translated to the planning process through protected area/buffer requirements (remembering that significant areas should already have been identified and excluded from logging e.g. stream buffer areas, cultural sites). When determining additional protected area specifically for habitat requirements consideration needs to be given to:

- whether the identified land-use priority is for timber production and sufficient area is available for profitable timber production activity;

- corridors and their design;

- fragments, fragment size/shape and interconnectedness of fragments;

- location of fragments; and

- location of habitat outside the plantation estate.

In developing and maintaining corridors and fragmented areas planners must be aware that these areas despite being reserved are frequently exploited by the local population. As a result, adequate provision for the needs of the local population and their socio-economic status is critical to maintenance of areas targeted for biodiversity conservation. Location of these exclusion zones should also be as remote from population centres and road networks as possible.

Many communities while utilising an area will also conserve that area due to its value for ongoing utilisation. Exclusion zones can therefore be designed which may achieve both a biodiversity protection goal as well as providing for the needs of the local community. It is recommended that communities be consulted as to important plant and animal species. Exclusion zones should be then designed using these species as indicators. This will assist to ensure the preservation of these areas through low level exploitation. 


\subsection{Exclusion Zones for Landscape Level Planning}

Seven types of exclusion zone exist at the landscape planning level. There is to be no logging or plantation establishment in these exclusion areas. Exclusion areas include:

- buffer areas on stream sides and gullies;

- areas of cultural significance;

- buffer areas on shorelines, lagoons, lakes, swamps and water storage areas;

- buffer areas on land-slip areas;

- areas over 25 degrees slope;

- areas of identified habitat for rare or endangered species e.g. caves used for bird nesting sites; and

- areas of significant forest types e.g. mangrove forests.

These areas must be:

- delineated on the GIS/map and demarcated on the ground prior to commencement of harvesting or clearing; and

- they must remain intact before during and after development of the plantation

\section{Buffer Areas}

Buffer areas are a type of exclusion zone created around sensitive forest areas to protect them from damage.

Table 3.1 shows the types of buffers and recommends minimum buffer widths. Note that individual countries may have legislation which prescribes the legal buffers. In this situation the legal buffers should apply.

A simple flow chart for determining watercourse type is located in Figure 3.1. 
Table 3.1 Buffer Area Protection Guidelines

\begin{tabular}{|c|c|c|}
\hline Feature & Definition & Buffer (m) \\
\hline Streams & $\begin{array}{l}\text { Streams are those watercourses where water mayflow for more than } \\
2 \text { months in most years. } \\
\text { Class } 1 \text { streams }- \text { width of the stream-base }=\text { more than } 20 \text { metres } \\
\text { Class } 2 \text { streams }- \text { width of the stream-base }=10 \text { to } 20 \text { metres } \\
\text { Class } 3 \text { streams }- \text { width of the stream-base }=\text { less than } 10 \text { metres }\end{array}$ & $\begin{array}{l}30 \mathrm{~m} \text { each side } \\
20 \mathrm{~m} \text { each side } \\
10 \mathrm{~m} \text { each side }\end{array}$ \\
\hline Gullies & $\begin{array}{l}\text { Gullies are steep-sided channels where water flows for less } \\
\text { than } 2 \text { months in most years where the slope of at least } \\
\text { one bank exceeds } 25 \% \text {. }\end{array}$ & $10 \mathrm{~m}$ each side \\
\hline Cultural areas & $\begin{array}{l}\text { Cultural areas are determined through discussions with local } \\
\text { communities }\end{array}$ & $30 \mathrm{~m}$ \\
\hline $\begin{array}{l}\text { Swamps } \\
\text { Lakes } \\
\text { Lagoons } \\
\text { Shoreline } \\
\text { Water storage } \\
\text { areas }\end{array}$ & $\begin{array}{l}\text { - Swamps have surface water present for } 6 \text { months or more of the year. } \\
\text { - The buffer width is measured from the high water mark or edge of } \\
\text { the mangrove vegetation if this occurs above the high water mark. } \\
\text { - A } 30 \mathrm{~m} \text { strip may be cleared to the waters edge for a wharf. }\end{array}$ & $50 \mathrm{~m}$ \\
\hline Landslip areas & $\begin{array}{l}\text { Landslip areas include the spoil and the area from which } \\
\text { the spoil came. }\end{array}$ & $10 \mathrm{~m}$ \\
\hline Steep areas & Areas over 25 degrees slope. & Protected \\
\hline Habitat & $\begin{array}{l}\text { Areas identified by an ecologist which are essential for the survival } \\
\text { of key indicator species, species identified under the CITES } \\
\text { convention or rare and threatened species e.g. nesting sites, } \\
\text { food areas. }\end{array}$ & $\begin{array}{l}\text { As identified } \\
\text { by an ecologist }\end{array}$ \\
\hline $\begin{array}{l}\text { Significant } \\
\text { forest types }\end{array}$ & $\begin{array}{l}\text { Areas of forest type identified by an ecologist and communities as } \\
\text { being significant. }\end{array}$ & $\begin{array}{l}\text { As identified } \\
\text { by an ecologist }\end{array}$ \\
\hline
\end{tabular}

*measure from top of bank 
Figure 3.1 Procedure for Typing Watercourses

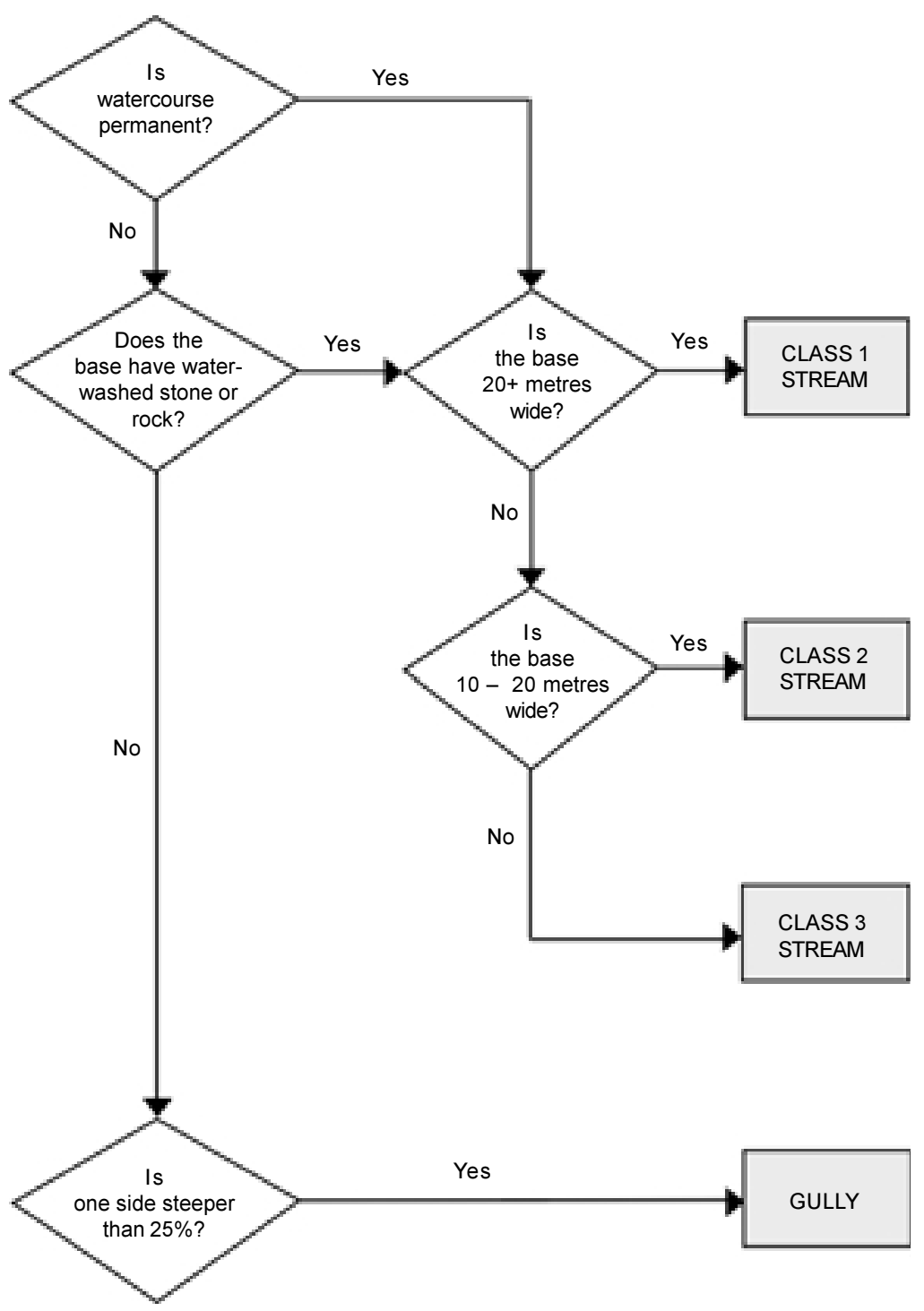




\section{Stand Level Planning}

\section{OBJECTIVES}

- Based on the Landscape Level Plan and a ground inspection, development of a plan for lang clearing and or establishment prior to commencement of operations.

- To minimise the loss of productive plantation area while protecting any exclusion zones.

During the plantation development phase, Stand Level Plans must be prepared for each individual plantation block. These are based on the Landscape Level plan and a site inspection. This is done prior to operations commencing. A plan of the block and attached written plan will identify:

- Any relevant exclusion zones/buffers from the Landscape Level Plan.

- Any additional internal exclusion zones identified which include:

- cultural/religious sites;

- areas of important habitat e.g. breeding sites; and

- $\quad$ steep or rocky areas within the block not identified at the landscape level.

- Major and minor roads (existing and planned).

- Watercourses and their class.

- Contour lines.

- Internal and external firebreaks.

- Landings and skid trails for the harvest operation.

- Staff responsibilities and work requirements that include road construction, land clearing and site preparation. 


\section{Roading and Drainage}

\section{OBJECTIVES}

- To plan a roading system which is safe economical and minimises the loss of productive plantation area.

- To minimise sedimentation of watercourses and disturbance to excluded areas.

- To provide and maintain good surface and side drainage during and after construction of roads to maximise road life.

Road planning and construction guidelines apply to both the landscape level operations when the major road network is developed and to the stand level when the minor roads and access tracks are constructed. At both levels, effective planning of the roading system will result in lower costs and less environmental and social disturbance than without effective planning.

\subsection{Road Classification}

\begin{tabular}{|l|l|}
\hline \multicolumn{1}{|c|}{ Road class } & \multicolumn{1}{c|}{ Definition } \\
\hline Major road & $\begin{array}{l}\text { Can carry trucks with large log volumes up to } 2,500 \mathrm{~m}^{3} \text { of } \\
\text { wood a week or more }\end{array}$ \\
\hline Minor road & $\begin{array}{l}\text { Can carry trucks with moderate log volumes up to } 2,500 \mathrm{~m}^{3} \\
\text { of wood per week }\end{array}$ \\
\hline Access track or fire break & $\begin{array}{l}\text { Accessible only in dry weather and capable of carrying } \\
\text { a standard 4 wheel drive vehicle }\end{array}$ \\
\hline
\end{tabular}




\subsection{Road Design}

\section{Location}

Roads should be located according to the following:

- follow the easiest topography while accessing the greatest area of plantation possible (minimise side/thru cuts);

- use areas of low side slopes;

- locate roads so that no earthworks or soil spill should fall into watercourse buffer areas;

- minimise the number of watercourse crossings;

- balance cuts and fills to minimise transport of road construction material; and

- in swamp forests, roads are inappropriate in most cases, so temporary railway systems (or other similar low impact transportation system) located on a grid pattern should be planned for log extraction.

- Figure 5.1 shows appropriate road location and drainage features.

\section{Areas to avoid}

Areas where roading should be avoided are:

- areas excluded from harvesting;

- locations which require box cuts (thru-cuts);

- areas subject to flooding; and

- steep and unstable areas. 
Figure 5.1. Road Location and Drainage

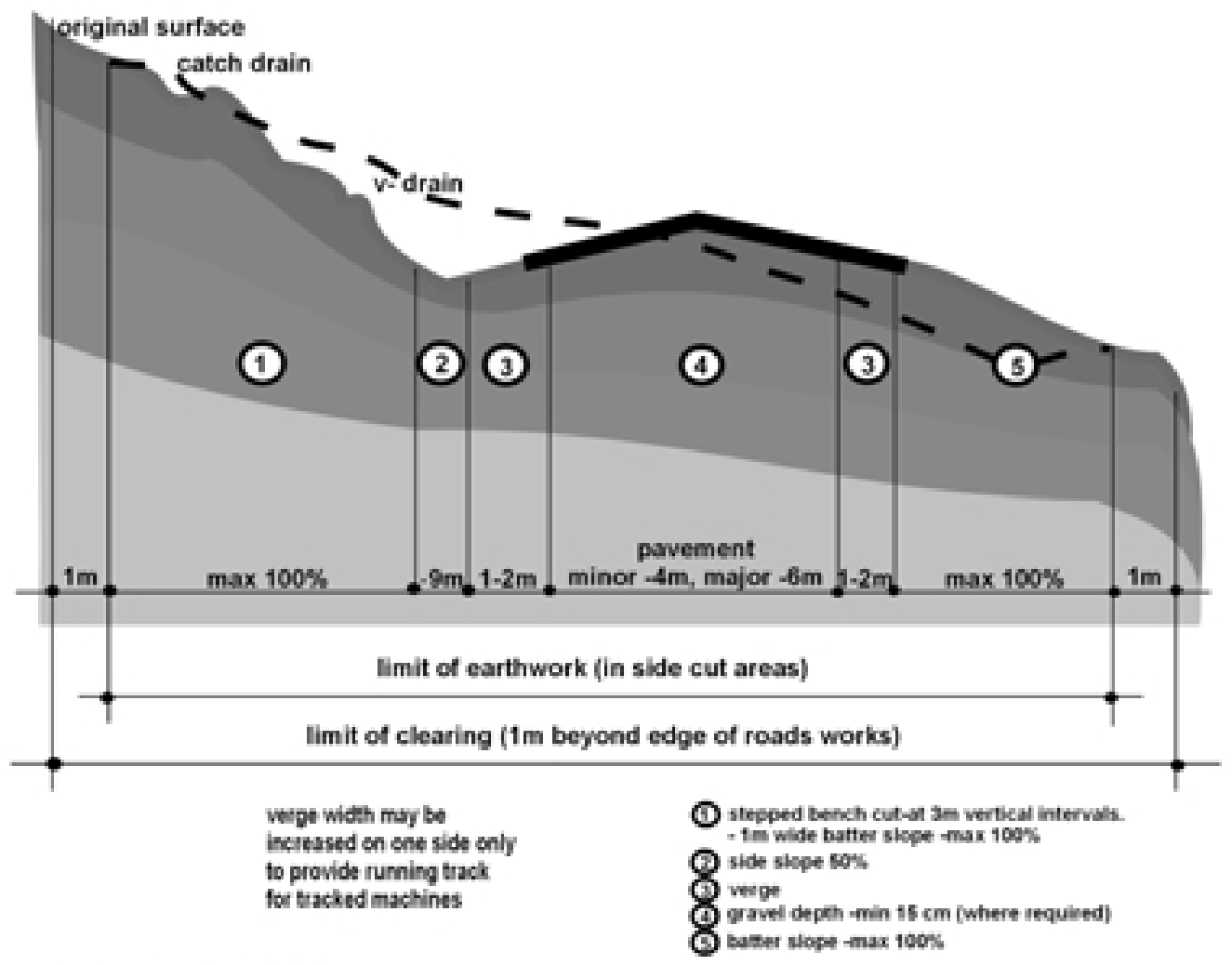

\section{CROSS SECTION}

Suggested maximum side slopes

- $50 \%$.

Suggested maximum batter slopes

- $100 \%$. 


\section{Road grade specification}

\begin{tabular}{|l|c|c|c|}
\hline Road class & $\begin{array}{l}\text { Preferred maximum } \\
\text { allowable grade (\%) }\end{array}$ & $\begin{array}{l}\text { Preferred maximum } \\
\text { adverse grade (\%) }\end{array}$ & $\begin{array}{l}\text { Preferred maximum } \\
\text { lenght at maximum grade (\%) }\end{array}$ \\
\hline Major road & 10 & 8 & $1000 \mathrm{~m}$ \\
Minor road & 15 & 10 & $750 \mathrm{~m}$ \\
Access track & $\mathrm{n} / \mathrm{a}$ & $\mathrm{n} / \mathrm{a}$ & $\mathrm{n} / \mathrm{a}$ \\
\hline
\end{tabular}

- Steeper grades (up to 20\%) for short sections (maximum $500 \mathrm{~m}$ ) are acceptable if this reduces disturbance from road construction.

- Any two sections of road at absolute maximum gradient should be separated by $100 \mathrm{~m}$ of level or lower gradient.

\section{Road widths}

Roading width should be kept to a minimum but will depend on the truck width and travel speed. Suggested maximum road widths are:

\begin{tabular}{|l|c|c|}
\hline & Gravel Surface & Compacted Clay Surface \\
\hline Major road (2-way) & $10.0 \mathrm{~m}$ & $15.0 \mathrm{~m}$ \\
Major road (1-way) & $6.3 \mathrm{~m}$ & $11.0 \mathrm{~m}$ \\
Minor road & $6.0 \mathrm{~m}$ & $7.3 \mathrm{~m}$ \\
Access track* & $4.0 \mathrm{~m}$ & $4.0 \mathrm{~m}$ \\
\hline
\end{tabular}

${ }^{*}$ Firebreaks are usually not gravelled

- Total road width from the edge of the cleared area on both sides of the road should be no greater than twice the road surface width except where benching is required. 


\section{Road corners}

Corner widening will be required to allow for trailer off-tracking (i.e. the trailer following a different path to the trucks front wheels). Recommended road curve radius and corner widening to allow for off-tracking on all road classes are:

\begin{tabular}{|l|l|l|c|}
\hline \multicolumn{1}{|c|}{ Design speed } & $\mathbf{3 0} \mathbf{~ k p h}$ & $\mathbf{5 0 ~ k p h}$ & $\mathbf{8 0 ~ k p h}$ \\
\hline Minimum radius (use may require signs) & $25 \mathrm{~m}$ & $30 \mathrm{~m}$ & $55 \mathrm{~m}$ \\
Desirable minimum radius & $35-75 \mathrm{~m}$ & $75-120 \mathrm{~m}$ & $140-300 \mathrm{~m}$ \\
Minimum sight distance required & $30 \mathrm{~m}$ & $64 \mathrm{~m}$ & $120 \mathrm{~m}$ \\
Meeting sight distance & $50 \mathrm{~m}$ & $100 \mathrm{~m}$ & $220 \mathrm{~m}$ \\
\hline
\end{tabular}

Off-tracking on curves (metres vs radius of curvature) based on a vehicle with overall length of $14 \mathrm{~m}$

\begin{tabular}{|c|c|c|c|c|c|c|c|c|c|}
\hline Radius (m) & 25 & 30 & 40 & 50 & 60 & 75 & 100 & 50 & 200 \\
\hline Off-tracking & 1.65 & 1.20 & 0.95 & 0.80 & 0.70 & 0.55 & 0.40 & 0.35 & 0.20 \\
\hline
\end{tabular}

NOTES: Additional width is required in each lane, i.e. a two-lane road requires a total widening to the roadway width of twice the tabulated value.

\subsection{Road and Access Track Construction}

\section{Timing of construction}

- Preliminary roadline clearing should be undertaken well ahead of final construction in any one site to reduce sedimentation from undrained sections.

- Major and minor roads are to be completed well before operations commence to allow the road to settle and stabilise. 


\section{Survey requirements}

- Survey and mark the centreline of roads and access tracks on the ground using the defined specifications.

\section{Roadline development}

- Organic debris should not be used as fill.

- Soil heaps, berms and debris stockpiling along roadside is prohibited and should be removed and/or burnt.

\section{Road construction}

- Where side cutting is necessary, they are to be formed as shown in Figure 5.2.

- Where side cutting is not necessary, earthworks should limited to the width allowed for the pavement plus verge and table drains on either side.

- Surfacing material can be either coral, crushed rock, compacted clay or gravel. 
Figure 5.2 Major and Minor Road Construction

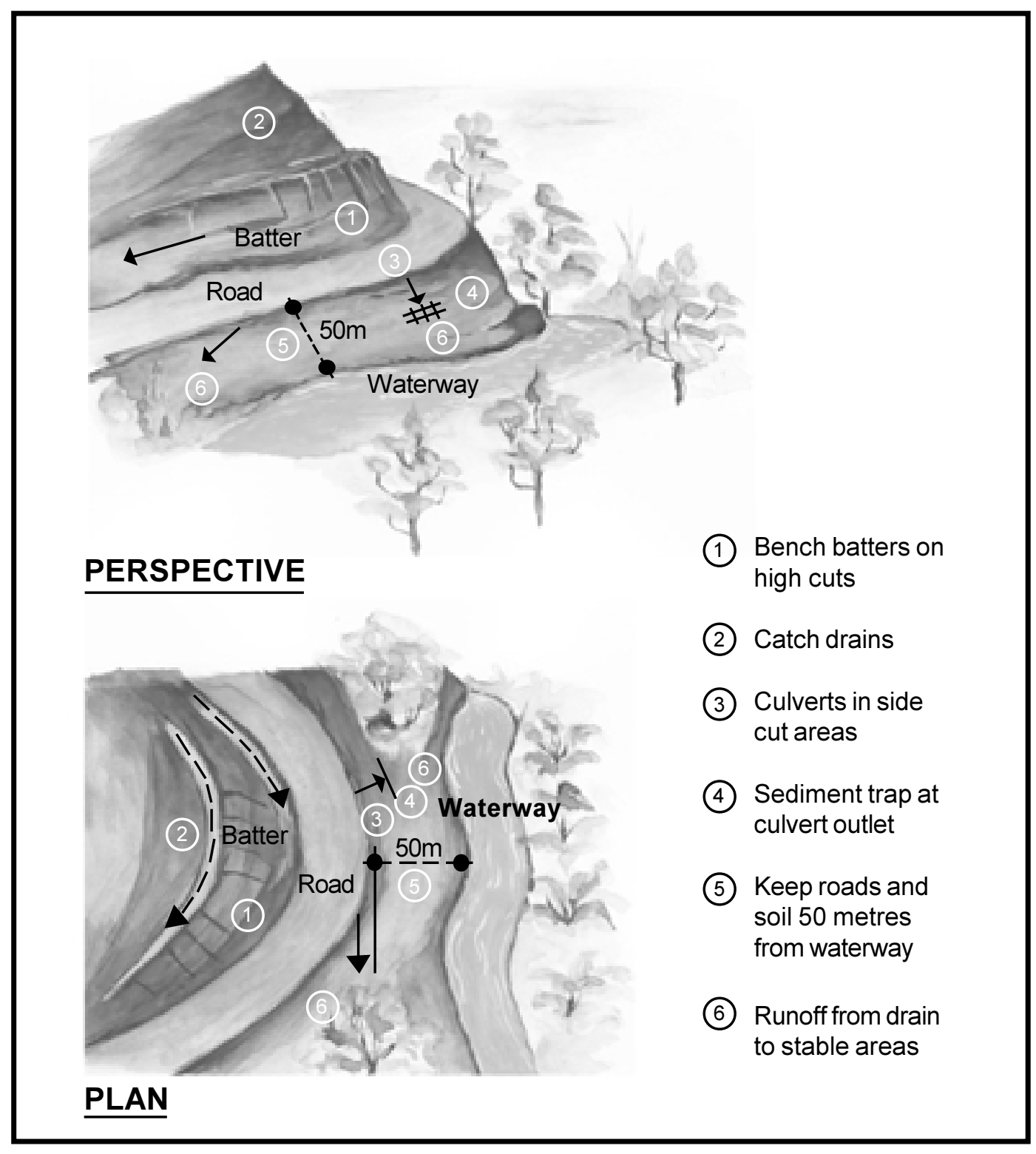




\section{Revegetating cut and fill areas}

Revegetation should be undertaken and can be carried out using a range of measures such as cereal cover crop (e.g. rice, millet), grass or seed of fast growing shrubs or trees immediately after construction. Detailed techniques for those activities are found in revegetation manuals.

\section{Limits to road construction}

- In wet weather road construction must cease.

- Road construction should be avoided during the wet season.

\section{Road drainage}

- Drain all roads to minimise sediment flow. Road drains should be constructed as follows:

- at changes of slope;

- within 50 metres of watercourse crossings;

- additional drains to meet the maximum spacing requirement.

- Side drains adjacent to roads which have been box-cut should have rock bars at half the maximum drain spacing.

Indicative drain spacings often used in many parts of the tropics are as follows:

\begin{tabular}{|c|c|c|}
\hline & \multicolumn{2}{|c|}{ Recommended maximum drain spacing (metres) } \\
\hline Centreline gradient (\%) & Unstable Soil & Stable Soil \\
\hline $0-15 \%$ & 40 & 60 \\
$15-20 \%$ & 20 & 40 \\
$20-25 \%$ & 10 & 20 \\
$25 \%+$ & - & 15 \\
\hline
\end{tabular}

It is suggested that roads are not built with grades exceeding $18 \%$.

Maximum truck grade is about $23 \%$. 
The following suggestions are made to promote suitably drained roads and access tracks.

- Convex road surface to create crossfall should be maintained at all times.

- The minimum earth fill over culvert pipes should be in accordance with manufacturer's guidelines, e.g. $600 \mathrm{~mm}$ for reinforced concrete pipe.

- Adequate provision should be made at culvert inlets and outlets to minimise erosion being caused by flow entering or discharging from the drain.

- Adequate provision of sumps or silt traps should be made to prevent siltation and blocking of culverts in high and very highly erodible soils.

- Culvert pipes should be laid on a grade of between $1 \%$ and $3 \%$ to minimise silting up of the pipes and excessive scouring at the discharge end.

- Where erosion of a road cutting face is likely, catchdrains should be constructed along the top sides of the cutting to collect surface run-off.

- Table drains should be dish-shaped and constructed to a minimum depth of $300 \mathrm{~mm}$ below the level of the top of the formation at the outer edge of the shoulder.

- Table drains should have a grade of 1-3\%.

- Drains are not to directly enter watercourses but should be diverted into surrounding vegetation at least $50 \mathrm{~m}$ before a watercourse.

- Drains must have stable outlets, protected by vegetation or by rock or log barriers, particularly in fill areas. 


\section{Access Track Drainage}

For access tracks cross drains should be used. The following spacings for cross drain are recommended and should be constructed as shown in Figure 5.3.

\begin{tabular}{|c|c|}
\hline Slope & Cross drain spacing \\
\hline $0-4 \%$ & Nil \\
$5-9 \%$ & $100 \mathrm{~m}$ \\
$10-19 \%$ & $60 \mathrm{~m}$ \\
$20-24 \%$ & $20 \mathrm{~m}$ \\
$25 \%+$ & $15 \mathrm{~m}$ \\
\hline
\end{tabular}

\section{Road maintenance}

- All drains, pipes, culverts and bridges are to be kept open at all times. They are to be inspected thoroughly and repaired before the onset of the wet season/monsoon and during periods of heavy rainfall.

- Road surface maintenance should be undertaken as needed. Crossfall and road shape should be maintained to allow effective drainage.

- Good surfacing gravel should not pushed to the road edge or into drains during surface maintenance. 
Figure 5.3 Cross-Drain System

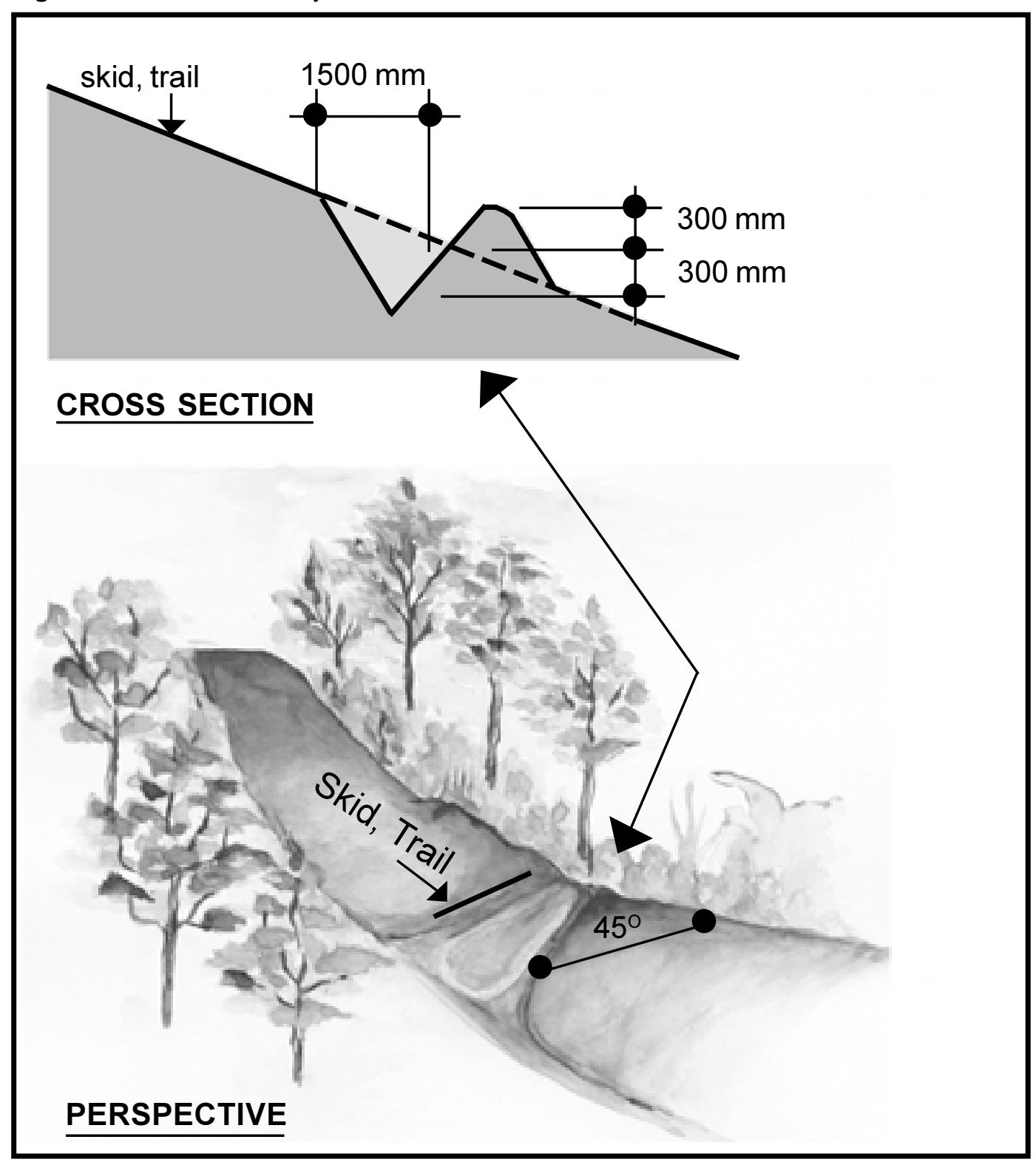




\section{Road Watercourse Crossings}

\section{OBJECTIVES}

- To provide permanent bridge or culvert crossings, constructed with durable materials over all watercourses crossed by roads.

- To restric disturbance to watercourses and surrounding buffer areas to that necessary for crossings.

- To minimise sedimentation of watercourses.

\subsection{Types of Crossings and Uses}

\begin{tabular}{|c|c|}
\hline $\begin{array}{l}\text { Type of } \\
\text { crossing }\end{array}$ & Situation in which crossing is used \\
\hline Bridge & $\begin{array}{l}\text { Must be used for road crossing of all Class } 1,2 \text { and } 3 \text { streams (except } \\
\text { where fords are acceptable). }\end{array}$ \\
\hline Culvert & $\begin{array}{l}\text { Must be used for crossing gullies (if bridges are not used). } \\
\text { FAO Watershed Management Field Manual Guide } 13 / 5 \text { provides } \\
\text { details for culvert sizes. }\end{array}$ \\
\hline $\begin{array}{l}\text { Ford or } \\
\text { Low level } \\
\text { crossing }\end{array}$ & $\begin{array}{l}\text { Fords are acceptable when: } \\
\text { - bank height of the watercourse is less than } 1 \text { metre; } \\
\text { - depth of normal waterflow across the ford is less than } 0.5 \text { metres; } \\
\text { - approaches to the stream are less than } 5^{\circ}(10 \%) \text {; } \\
\text { - the bed is solid (gravel or stone), with rock accumulation } \\
\text { downstream. }\end{array}$ \\
\hline Log clusters & $\begin{array}{l}\text { Log clusters with earth fill are not be permitted for any watercourse } \\
\text { in any situation. }\end{array}$ \\
\hline
\end{tabular}




\subsection{Construction of Watercourse Crossings}

\section{Location}

The chosen location of the watercourse crossing should:

- cross watercourse at right angles;

- select crossing points which;

- are immediately downstream of straight and stable watercourse sections;

- have easy high bank access;

- do not require deep box cuts; and

- require minimum alteration or disturbance to the high bank.

\section{Design}

- Permanent crossings must be of a size to allow wet season flood flows to pass without damage to the crossing or its foundations. Government authorities may be able to provide information on flood levels as will local inhabitants.

\section{Earthworks}

- Excavators should be used where possible for the construction of all watercourse crossings. Manual labour should also be considered as appropriate in specified circumstances.

- All earthworks should be carried out so as to prevent soil entering the watercourse. No soil is to be used or placed past the high bank without first having erected and secured a suitable barrier.

- No machinery will operate in the watercourse during construction.

- Road construction within the buffer area should be by end-haul.

- All spoil should be removed outside the buffer areas or placed in road fills where possible.

- Watercourse buffer vegetation should be retained to the edge of the crossing. 


\section{Foundations}

- Bridge and culvert foundations are to be located on stable materials.

- The foundations are to be excavated to a solid base and not formed on transported material.

\section{Bridges}

- Approaches must have a straight and level alignment for a minimum of 10 metres either side of the bridge.

- Decks can be constructed of durable sawn timber, or other non-erosive material (e.g. clean rock fill). Soil fill or soil covering is not permitted unless the timber deck is completely covered with material such as geotextile and has protection beams on both sides.

- The stream banks adjacent to the bridge, on both the top and bottom sides, must be stabilised using wings of durable logs, stone pitch or other equivalent construction

\section{Culverts and pipes}

- May have earth fill, but must have stable abutments constructed to the level of the running surface to prevent spoil entering watercourse.

- Scour pads (structure to minimise erosion) should be provided at culvert exits. They should be used if higher energy water flow is likely to occur (Figure 6.1).

- All culverts should have a cut-off wall to prevent erosion under the pipe.

- The head and outlet walls should be stabilised with log or stone pitched walls.

- Culvert gradients should be 1-3\%. 
Figure 6.1 Culvert Construction

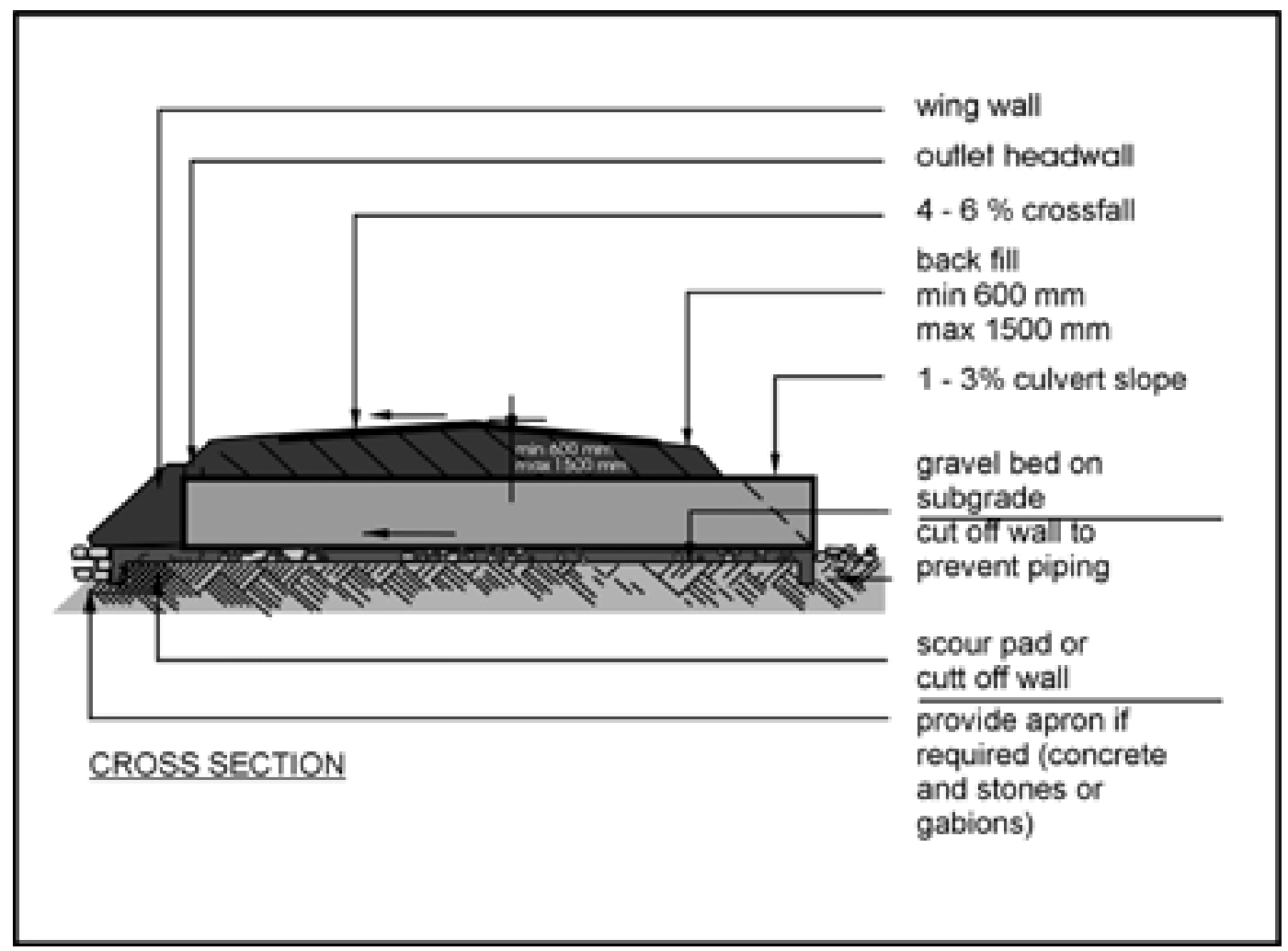




\section{Fords/Low level crossings}

Low level crossings should:

- minimise earth moving and impact on the stream bed;

- be built level to allow water to flow over them;

- have upstream debris deflectors above the crossing to deflect debris which could cause scouring above the crossing;

- enable deposited gravel to be removed and used for roading material; and

- provide for protection from scouring below crossing unless the bed is solid gravel or stone.

\section{Silt traps}

- Silt traps are to be provided at the four corners of bridges and culverts.

- Silt traps should be cleaned regularly. 


\section{Quarries}

\section{OBJECTIVES}

- To provide appropriate material for road/landing/log pond surfacing.

- To minimise disturbance to forest and watercourses.

\subsection{Sources of Quarry Material}

\begin{tabular}{|l|l|}
\hline \multicolumn{1}{|c|}{ Material source } & \multicolumn{1}{c|}{ Guidelines for selection } \\
\hline $\begin{array}{l}\text { Bedrock or Gravel from } \\
\text { Dryland Deposits }\end{array}$ & $\begin{array}{l}\text { - } \\
\text { - }\end{array}$ \\
\hline Euarries should be located within the stands, not in exclusion zones. \\
the formation of the road is preferred to the development of \\
large quarries.
\end{tabular}




\subsection{Quarry Management}

- The drains are to direct all runoff away from the quarry to vegetated areas. Drains must be constructed on the uphill side of the quarry to prevent runoff entering the quarry.

- The base of the quarry is to be drained at all times. Drains must not directly enter watercourses, but flow into buffer areas.

- Overburden including topsoil and organic debris should be stockpiled for spreading in the quarry surface when operations are completed. Runoff is not to pond in the stockpiled area.

- The face of the quarry is to be stable at all times.

- Rock blasting operations are to be carried out by certified personnel. Strict public safety measures are to be followed at all times with signs and guards posted at safe distances to prevent entry to the danger zone during blasting operations.

\subsection{Quarry Rehabilitation}

- Rehabilitation should occur progressively as quarry areas are no longer used.

- Removed overburden should be replaced followed by topsoil and organic matter.

- The site should be replanted/resown with trees, shrubs or a cereal crop. 


\section{Plantation Development at Stand Level}

\section{OBJECTIVES}

- To maximise the removal of material from the site simplifying plantation establishment.

- To minimise soil compaction, disturbance and erosion.

- To maintain organic material on site.

- To protect water quality, buffers and exclusion zones.

\subsection{Planning}

- Prior to development of any Stand, the Landscape Level Plans must be completed.

- The Stand Level Plan is then developed based on the Landscape Level Plan.

- Requirements of the Stand Level Plan are detailed in Section 4.

- If logging and clearing of vegetation is not required prior to cultivation (if required) and planting, Sections 8.1 - Section 9 are not applicable.

\subsection{Pre-harvest Activity}

- All roading must be completed prior to commencement of operations. Access tracks may be constructed during operations.

- All boundaries and buffer areas must be demarcated on the ground and operators made aware of the buffers.

- Landings and approximate major skid track locations should be identified and marked.

- Timber sale agreements must be in place. 


\subsection{Log Landings}

\section{Landing location}

Landings are to be located to maximise operational efficiency while minimising compaction. Use of roadsides is encouraged to reduce compaction. Landings must be located:

- outside areas excluded from harvesting;

- at least 40 metres from the edge of buffer areas;

- at sites which suit skidding pattern and direction;

- in dry areas on ridges or benches;

- in areas which are easy to drain;

- in areas of low slope to reduce the amount of side cutting; and

- on ridges to promote up hill skidding to disperse runoff into surrounding vegetation.

\section{Landing construction}

- Landing size should be kept to a minimum to reduce compaction (ideally less than $1000 \mathrm{~m}^{2}$.)

- Landings should be located so that free drainage occurs at all times.

- Split level landings may be used to reduce excavation. Safety must be paramount in design of split level landings as often found with Skyline Yarding Systems.

- To prevent the ponding of water, construct and drain landings to stable vegetated areas.

- Where the landing is to be used in wet weather, it should be "corded" using small logs of unmerchantable species.

\section{Landing operation}

- Landings must not be bladed off to keep them operational.

- Debris and waste heaps are to be more than 10 metres from drainage areas.

- Soil and vegetation debris are to be kept separate. 


\section{Landing rehabilitation}

- Landings should be restored so that proper drainage occurs to reduce soil erosion and runoff.

- If corded, cording should be removed.

- Bark and landing debris should be disbursed evenly across the landing to assist in stabilisation.

- Landings should be planted when the rest of the area is planted. This may require ripping to ameliorate compacted soil.

- The site should be cleaned of non biodegradable material and all solid waste removed, including oil/fuel drums and wire rope.

\subsection{Planning Skid Trails}

Major skid trail location should be pre-planned to:

- Avoid areas excluded from harvesting (other than at defined watercourse crossing points).

- Skid trails should not pass through Class 1, 2 or 3 streams without an appropriate crossing.

- Match with the landing location allowing minimum skid distances for maximum log volume.

- Use spur lines where possible, to allow good drainage.

- Where major skid trails must cross slopes, the angle of the skid trail to the contour should not exceed $100 \%$.

- Advisable maximum slope for side cutting is $50 \%$.

- In some instances, it may be appropriate to cord some or all of the skid trail length.

\section{Stream or Gully crossings}

- Select crossing points on waterways in places where:

- bank slope is less than $18 \%$ (preferably less than $9 \%$ );

- the bed is firm. 
- Skid trails should cross watercourses at right angles.

- Temporary crossings are to be provided if water is flowing at the time of operation.

\section{Construction}

- Construct crossings in dry weather.

- Width of the crossing is to be less than 4 metres. Buffer vegetation is not to be otherwise disturbed.

- Use unmerchantable logs for the crossing where appropriate.

- Cording of the approaches to the crossing may be required within 2 metres of the high bank.

- Soil is not to be pushed:

- past the high bank;

- into watercourses;

- onto the top of the crossing.

- Construction must not occur in wet weather.

\subsection{Harvesting Operations}

It is suggested that tree felling be practiced as a two stage operation to maximise extracted volume and minimise residue on site. Initially trees less than $30 \mathrm{~cm}$ diameter should be cut and extracted. The remaining large timber can then be cut and extracted. Falling should be carried out on a working face with operators a minimum of two full tree lengths apart. It is suggested that fallers should be operating in separately marked blocks to ensure they are always a safe distance apart. If some or all wood cannot be sold then falling should aim to concentrate and compact slash.

- Harvest operations must be controlled by experienced supervisory staff who inspect the site frequently.

- Harvesting can commence when all planning is completed and exclusion zones are clearly demarcated. 
- As much material as possible should be removed from the site to simplify plantation establishment.

\subsubsection{Tree Felling}

\section{Testing tree soundness}

- Trees, suspected of being unsound, should be tested before felling.

\section{Preparation}

- Plan the direction in which to fell the tree based upon (in order of priority);

1) safety for the feller (beware of dead limbs or "hung-up" branches);

2) avoidance of buffer areas and exclusion zones; and

3) to facilitate extraction.

- Clear 2 alternative escape routes away from the tree to be felled.

- Clear shrubs and saplings away from the base of the tree to provide an adequate working space.

- Tree fellers are not obliged to fell any tree that they feel is unsafe to fell.

\section{Felling}

- Scarf and back-cut as appropriate.

- Retain hinge wood.

- Use wedges where appropriate to control falling direction.

\section{Stump height}

- Stump height should be as low as practicable $(<30 \mathrm{~cm}$ is preferable) to maximise merchantable volume and simplify site preparation. 


\section{Using machines to assist felling and remove hung-up trees}

- The use of machines to pull trees while they are being cut is prohibited.

- Machines, fitted with international standard roll-bar protection, are preferable to use to dislodge hung-up trees.

- Hung-up trees are to be removed before any more trees are harvested. If they cannot be removed immediately, the area is to be well marked to signal the danger to other people.

- Adopt ILO Code of Practice on Safety and Health in Forest Work.

\section{Limitations}

- Tree felling operations must cease in wet weather.

\subsection{Log Cross-cutting and Debranching}

- Completely cross-cut (bucking) logs so that splitting does not occur when the log is moved during skidding.

- Cross-cut boles and tops to obtain the maximum volume, consistent with highest value of saleable logs.

- Trim all buttress flutes and side branches flush with the main stem to:

- gain maximum log quality and volume; and

- reduce soil disturbance and assist skidding.

- Ensure that cross-cuts are no more than $10^{\circ}$ from vertical.

- Use log nails or S nails on $\log$ ends to avoid end splitting and to maintain quality.

\section{Cross-cutting safety}

- Do not stand on the trunk of the tree being cross-cut.

- Beware of tension while cutting logs and if necessary make a cut on the compression side to reduce the tension before making the final cut. 
- Avoid using the tip of the chainsaw cutter bar as this can cause kickback.

- Use an appropriate wedge to avoid the chainsaw jamming in the log.

- Avoid making the final cut while standing on the lower side of a tree if it is lying on a slope.

- When making the final cut always stand on the compression side of the log.

- Beware of overhead hazards.

\subsubsection{Skidding operations}

\section{Extraction Systems}

A range of extraction systems may be used. Selection of an appropriate system will depend on the site, the available equipment and the desire to minimise compaction. To provide assistance in matching extraction systems to various sites, slopes and soil types, the following table is provided: 


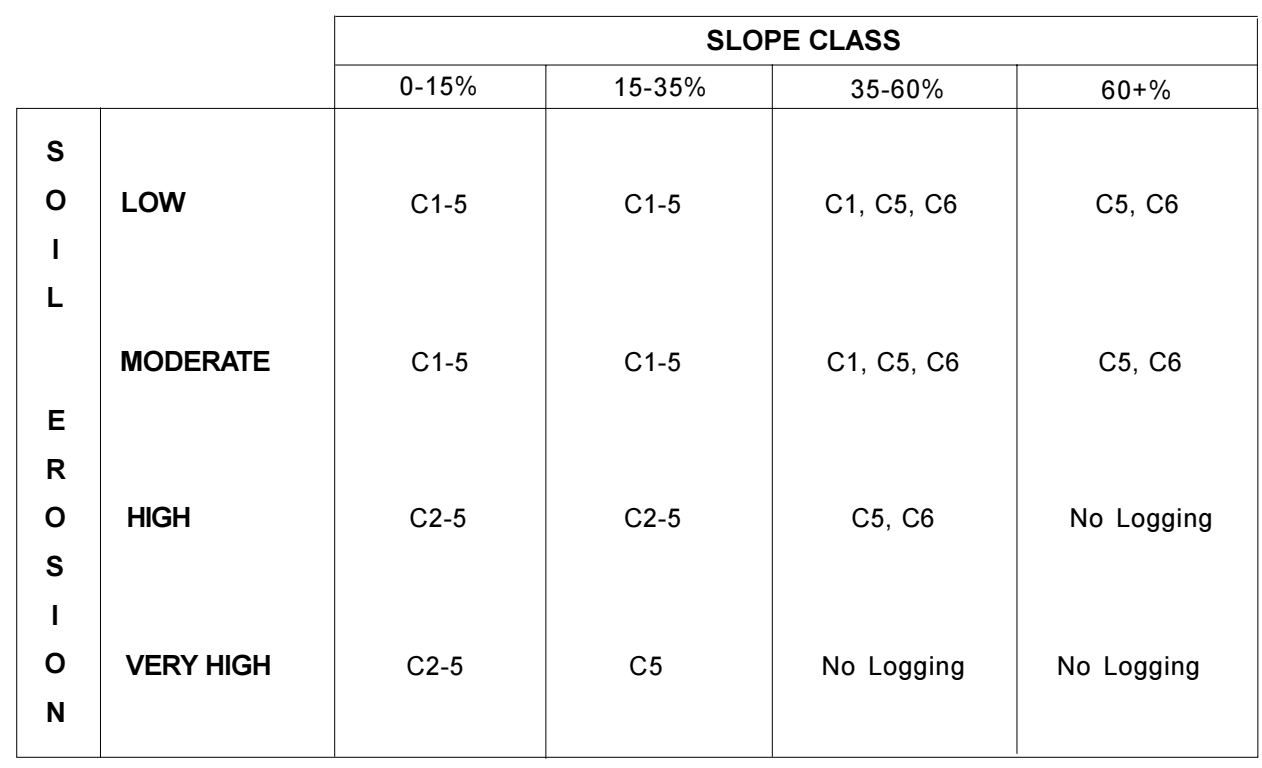

C1 Crawler Tractor - Capacity to result in high levels of compaction if poorly used.

C2 Skidder/Forwarder - Capacity to result in high levels of compaction if poorly used.

C3 Flexible Track machines (FMC)/Low Ground Pressure Tractors - Moderate compaction if poorly used.

C4 Draught Animals/Human Beings - Low compaction.

C5 Helicopter - No compaction.

C6 Skyline Yarding System - High levels of compaction at landing but low elsewhere.

\section{Mechanical Skidding}

- Tractor blades should be raised or removed when travelling and skidding.

- Minimise the number of passes of the machine across any area.

- Use winch cables to minimise machine use on the site and reduce compaction. This is particularly important on steep country.

- Where possible skid trails should approach landings from below to avoid directing runoff water onto the landing. 
- Pushing soil on skid trails $<25 \%$ slope, other than that permitted for construction, is to be avoided.

- Retain vegetation litter and tree tops along trails to protect mineral soil.

- Reverse along skid trails towards the log, wherever this can be done safely.

- Where possible use winch ropes and avoid driving to the tree stump.

- If possible lift the end of the log off the ground, to avoid soil damage due to log drag. Logging arches will assist with this action.

\section{Limits on skidding operation}

- No skidding in areas excluded from logging.

- No skidding should occur in wet conditions or on saturated soils.

\section{Skyline Yarding}

Skyline yarding systems are appropriate extraction systems for harvesting on steep sites (36\% or more). When using skyline systems:

- Logs must be fully suspended across buffer areas.

- Cables may be pulled through buffers but cannot be dragged horizontally to the angle of pull.

\subsubsection{Log Storage}

- Avoid stockpiling logs which are susceptible to decay or insect attack.

- Stockpile logs at well drained roadside landings, accessible in wet weather.

\subsubsection{Log Transportation Systems}

- Log transportation systems must be designed to load and haul logs safely.

- Excavators should be used for loading logs where possible.

- Trucks must not be loaded in excess of their design capacity. 
- All loads are to be secured with at least 2 approved load binders.

- Protruding limbs or trailing material must be removed before the truck departs the loading point.

- Rafted or barged logs must be well secured to avoid loss and damage to other vessels on the waterway.

\subsection{Weather Limitations on Harvesting}

The responsibility for defining when weather conditions restrict harvesting operations lies with the on-ground supervisor/manager. Operating when conditions are excessively wet, causes extreme damage to soil and water. It is also inefficient and often dangerous.

\subsection{Monitoring and Evaluation of Development Activity}

- Formal evaluation of operations will be done by management staff on a regular basis (every two weeks).

\section{Evaluation procedures}

- A simple operation evaluation form is located in Table 8.1.

- All evaluations will require ground inspection.

- The manager should be accompanied by the staff member responsible for the activity being inspected.

- Areas inspected and evaluated will include a representative sample of:

- current harvesting/establishment operations;

- areas completed since the last inspection;

- $\quad$ areas where the staff were directed, at the previous inspection, to do further work.

- During the inspection, all areas of non-compliance with the Code or the harvesting contract are to be explained to the relevant employees.

- A warning for non-compliance will be issued to staff for a significant breach of the Code and penalties for a further non-compliance identified (e.g. fine, demotion).

- If a further non-compliance occurs penalty action should be taken. 
Table 8.1 Evaluation form

\section{OPERATIONS CHECKLIST and EVALUATION FORM}

Date: $\quad$ Place: $\quad$ Company Rep.: Staff member present:

\begin{tabular}{|c|c|c|c|}
\hline $\begin{array}{c}\text { CODE } \\
\text { (1) }\end{array}$ & $\begin{array}{c}\text { ACTIVITY } \\
\text { (2) }\end{array}$ & $\begin{array}{l}\text { CORRECT } \\
\text { PROCEDURE } \\
\text { (Trick) } \\
\text { (3) }\end{array}$ & $\begin{array}{l}\text { INCORRECT } \\
\text { PROCEDURE } \\
\text { (Trick) } \\
\text { (4) }\end{array}$ \\
\hline $\begin{array}{l}1.0 \\
1.1 \\
1.2\end{array}$ & $\begin{array}{l}\text { PLANNING } \\
\text { Landscape Level Plan has been completed in } \\
\text { accordance with the Code. } \\
\text { Stand Level Plan has been completed in } \\
\text { accordance with the Landscape Level Plan } \\
\text { and the Code. } \\
\text { Exclusion zones and buffers marked in field } \\
\text { according to Operational Plan. }\end{array}$ & & $\begin{array}{l}\text { Operations may not } \\
\text { proceed until } \\
\text { compliance achieved } \\
\text { Operations may not } \\
\text { proceed until } \\
\text { compliance achieved } \\
\text { Operations may not } \\
\text { proceed until } \\
\text { compliance achieved }\end{array}$ \\
\hline $\begin{array}{l}2.0 \\
2.1 \\
2.2 \\
2.3\end{array}$ & $\begin{array}{l}\text { ROADING (Access } 2 \text { lengths of approximately } \\
100 \mathrm{~m} \text { ) } \\
\text { Road length located as per Landscape and or Stand } \\
\text { Level Plan. } \\
\text { No clearing beyond } 10 \mathrm{~m} \text { at widest point. } \\
\text { Stream crossings constructed as per Code and Plans. }\end{array}$ & & \\
\hline $\begin{array}{l}3.0 \\
3.1 \\
3.2 \\
3.3\end{array}$ & $\begin{array}{l}\text { LANDINGS (Access } 2 \text { landings) } \\
\text { Landing located as per harvesting plan. } \\
\text { Landing less than } 0.1 \text { ha. } \\
\text { Landing } 40 \mathrm{~m} \text { from any exclusion zone. }\end{array}$ & & \\
\hline
\end{tabular}


Table 8.1 Continued

\begin{tabular}{|c|c|c|c|}
\hline $\begin{array}{l}\text { CODE } \\
(1)\end{array}$ & $\begin{array}{l}\text { ACTIVITY } \\
\text { (2) }\end{array}$ & $\begin{array}{c}\text { CORRECT } \\
\text { PROCEDURE } \\
\text { (Trick) } \\
\text { (3) }\end{array}$ & $\begin{array}{c}\text { INCORRECT } \\
\text { PROCEDURE } \\
\text { (Trick) } \\
\text { (4) }\end{array}$ \\
\hline 4.0 & EXCLUSION ZONES/BUFFERS (Assess 1 area) & & \\
\hline 4.1 & $\begin{array}{l}\text { Exclusion zone/Buffer located according to Landscape/ } \\
\text { Stand Level Plan. }\end{array}$ & & \\
\hline 4.2 & Exclusion zone/Buffer with no trees felled in it or into it. & & \\
\hline 4.3 & Exclusion zones/Buffer with no unauthorised machine entry. & & \\
\hline 5.0 & $\begin{array}{l}\text { SKIDDING (Assess } 2 \text { lengths of approximately } \\
60 \mathrm{~m} \text { ) }\end{array}$ & & \\
\hline 5.1 & Skid track marked and located as per Stand Level Plan. & & \\
\hline 5.2 & Skid track not in an Exclusion zone/Buffer. & & \\
\hline 5.3 & No unnecessary blading. & & \\
\hline 5.4 & Logs winched to the skid track, not extracted from the stump. & & \\
\hline 6.0 & DIRECTIONAL FALLING (Assess 3 stumps) & & \\
\hline 6.1 & For each tree fallen with correct falling techniques. & & \\
\hline 7.0 & SITE PREPARATION (Assess stand area) & & \\
\hline 7.1 & Fire usage minimised or avoided totally. & & \\
\hline 7.2 & $\begin{array}{l}\text { Any site preparation operations conducted along } \\
\text { the contour. }\end{array}$ & & \\
\hline 8.0 & ESTABLISHMENT (Assess stand area) & & \\
\hline 8.1 & Chemical usuage minimised and applied appropriately. & & \\
\hline 8.2 & Trees planted at planned spacing. & & \\
\hline 8.3 & Roots of trees planted directly downward. & & \\
\hline & INSPECTION SUMMARY & & \\
\hline
\end{tabular}




\section{Log Pond and Wharf}

\section{OBJECTIVES}

- To minimise the area for processing and shipping of logs.

- To avoid adverse impact on the marine environment.

- To prevent log off-casts from entering watercourses or the sea.

\subsection{Location}

- A log pond and wharf loading ramp plan, showing the location and construction specifications should be submitted to the relevant authority prior to construction.

- Gently sloping areas (up to 6\%) are preferred to promote drainage.

- Construction of log ponds by fill reclamation areas below low water mark will only be considered where:

- there is no alternative;

- construction and operation will not damage the adjacent marine environment; and

- drainage water is directed away from the sea.

- Locate to provide the best and most direct access for log ship barges. Deep water ports are preferred to reduce the cost and disturbance associated with barging operations.

- Retain a 50 metre buffer area between the log pond and the shoreline (or mangrove vegetation) or a watercourse.

- Clearing of shoreline or river frontage vegetation (including mangroves) is limited to that necessary to construct the wharf and associated log storage area. A maximum frontage of 100 metres is desirable. 


\subsection{Timing of Construction}

- Construct the log pond and wharf in dry weather.

- Excavators should be used where possible for construction to minimise disturbance to surrounding environment.

\subsection{Design}

\section{Log pond}

- Log pond areas are to be well drained. Spoon drains (3-4 metres wide and $30 \mathrm{~cm}$ deep), constructed at a maximum interval of 40 metres will channel runoff to vegetated outlets. The maximum slope of spoon drains should be $1-3 \%$.

- The major crossing points of drains are to be gravelled to a depth of $30 \mathrm{~cm}$. The gravel is not to restrict the flow of water along drains. Where gravel is not available, crossing points are to be corded so that the top of the cording is level with the base of the drain.

- Drains are not to directly enter water bodies but must run through vegetation.

- Log and waste storage areas between the drains are to be elevated with a crossfall of 4-6\% and at least $1 \mathrm{~m}$ above high tide level.

- Fuel storage areas should be bunded and located at least $50 \mathrm{~m}$ from the high tide mark.

\section{Wharf}

- Construct using clean gravel fill only. Soil material should not be used.

- The loading face of the wharf is to be a wall construction with a top log. Walls may be constructed of round timbers, rock or other material able to prevent slumping of wharf fill into the sea. All timbers are to be secured to prevent their falling into the sea. Only durable timber species should be used. 


\section{Barging/Beach Loading}

An area should be selected which will:

- Minimise damage to the shoreline; and

- Minimise the requirement for machinery to enter the water.

- Adequate drainage as detailed for log ponds must be installed.

- If damage from vehicles is to occur on the waterline strip, then cording should be installed.

\subsection{Maintenance}

- Drains are to be kept open at all times.

- Silt traps are to be cleaned regularly.

- Log storage areas and the surface of the wharf are to be kept elevated by applying gravel or coral as required.

\subsection{Decommissioning/Rehabilitation}

- The drainage system should prevent stormwater runoff from the site entering watercourses or the ocean without first passing through a filter strip. Cross drains may be required.

- All stream beds must be restored to allow unimpeded flow of water.

- All refuse, waste oil and fuel must be removed from the site.

- Cording must be removed if used. 


\section{Plantation Establishment}

\section{OBJECTIVES}

- To prepare the site for planting in the most economical and efficient way while ensuring good tree growth.

- To minimise herbicide, pesticide and fertiliser use.

- To establish successful plantations with the best techniques available.

\subsection{Site Preparation}

At the completion of harvesting operations the site will be covered with residual timber not removed in the harvest operation. Some of this timber will be on the ground and some still standing. A range of techniques can be used to prepare the site for planting. These may include 1 or more of the following:

- Planting in rows directly into the site without site preparation. This is possible if residue is small in size and is less than $10 \mathrm{t} / \mathrm{ha}$.

- Row clearing by hand or with machine to allow line planting.

- Pushing and/or heaping timber to form windrows. Windrows should run along the contour.

- Windrow burning in preference to broadcast burning.

- Chopper rolling to break smaller timber up and knockdown remaining standing timber. This may be done immediately or after leaving the site fallow for 1-2 years to allow material to breakdown.

- Ripping along the contour to create a defined planting line and assist root penetration.

- Mounding along the contour to concentrate topsoil and bring seedling roots into aerated soil if waterlogging is of concern. 
It should be noted that best practice means no minimal use of fire for site preparation. Fire causes immediate loss of nitrogen, destroys soil organic matter and increases the loss of nutrient and soil offsite post burning. The result will be poorer plantation growth rates in the longterm.

A decision on the most appropriate site preparation system will depend on the species to be established, the site and available equipment. To assist in systems selection some advantages and disadvantages of different systems are listed in Table 10.1. 


\section{Table 10.1 Summary of Site Preparation Systems}

\begin{tabular}{|c|c|c|c|}
\hline System & Requirements & Advantages & Disadvantages \\
\hline \multirow[t]{2}{*}{ Row clearing } & Hand labour & $\begin{array}{l}\text { Usually labour available. } \\
\text { Can be done at same time as } \\
\text { planting. } \\
\text { Maintains a vegetated interrow } \\
\text { protecting soil. }\end{array}$ & $\begin{array}{l}\text { Slow. } \\
\text { Often far greater weed control } \\
\text { problem due to maintenance } \\
\text { of interrows. }\end{array}$ \\
\hline & Dozer/Skidder & Fast and simple. & Some compaction. \\
\hline Windrowing & $\begin{array}{l}\text { Dozer/Excavator } \\
\text { Stick rake }\end{array}$ & $\begin{array}{l}\text { Clean site, easy to plant and for } \\
\text { later operations. }\end{array}$ & $\begin{array}{l}\text { Often push some topsoil into } \\
\text { windrows. } \\
\text { Windrows may take many years } \\
\text { to rot away. } \\
\text { Loss of productive area. }\end{array}$ \\
\hline $\begin{array}{l}\text { Windrow } \\
\text { burning }\end{array}$ & $\begin{array}{l}\text { Labour } \\
\text { Fire prevention } \\
\text { equipment }\end{array}$ & $\begin{array}{l}\text { Maximises productive area. } \\
\text { Makes site access simple. } \\
\text { Provides large immediate nutrient } \\
\text { source but only on windrows. }\end{array}$ & $\begin{array}{l}\text { Risk of fire escape and damage } \\
\text { to exclusion zones and other } \\
\text { plantations. } \\
\text { Loss of nutrients from site imme- } \\
\text { diately (e.g. organic matter, ni- } \\
\text { trogen) and post burning through } \\
\text { erosion resulting in longterm pro- } \\
\text { ductivity losses. } \\
\text { Difficulty in finding suitable } \\
\text { weather conditions for a success- } \\
\text { ful burn. }\end{array}$ \\
\hline $\begin{array}{l}\text { Chopper } \\
\text { rolling }\end{array}$ & $\begin{array}{l}\text { Dozer (D7 or larger) } \\
\text { Chopper drums }\end{array}$ & $\begin{array}{l}\text { Maintains nutrient on site. } \\
\text { Maintains soil cover reducing } \\
\text { compaction and erosion. } \\
\text { Provides a relatively easy to plant } \\
\text { site. }\end{array}$ & $\begin{array}{l}\text { Need large machine to pull } \\
\text { chopper roller. } \\
\text { May require some windrowing if } \\
\text { still much large timber left on } \\
\text { site. }\end{array}$ \\
\hline
\end{tabular}


Table 10.1 Continued

\begin{tabular}{|c|c|c|c|}
\hline System & Requirements & Advantages & Disadvantages \\
\hline $\begin{array}{l}\text { Broadcast } \\
\text { burning } \\
\text { (Considered } \\
\text { poor practice) }\end{array}$ & $\begin{array}{l}\text { Labour } \\
\text { Fire control } \\
\text { equipment } \\
\text { Suitable } \\
\text { weather } \\
\text { conditions }\end{array}$ & $\begin{array}{l}\text { Easy. } \\
\text { Low cost. } \\
\text { Provides large immediate nutrient } \\
\text { source. }\end{array}$ & $\begin{array}{l}\text { Risk of fire escape and damage } \\
\text { to exclusion zones and other } \\
\text { plantations. } \\
\text { Loss of nutrients from site } \\
\text { immediately (e.g. organic matter, } \\
\text { nitrogen) and post burning } \\
\text { through erosion resulting in } \\
\text { longterm productivity losses. } \\
\text { Difficulty in finding suitable } \\
\text { weather conditions for a succesful } \\
\text { burn. }\end{array}$ \\
\hline Ripping & Dozer & $\begin{array}{l}\text { Allows root penetration and } \\
\text { increases tree stability. } \\
\text { Increases water inflow to soil. }\end{array}$ & $\begin{array}{l}\text { Increases likelihood of soil } \\
\text { movement. } \\
\text { In some soils a large machine is } \\
\text { required to successfully rip. } \\
\text { Does not enhance tree growth on } \\
\text { some soils. }\end{array}$ \\
\hline Mounding & $\begin{array}{l}\text { Dozer/Skidder } \\
\text { Plough }\end{array}$ & $\begin{array}{l}\text { Increases top soil concentration } \\
\text { around tree. } \\
\text { Reduce weed competition in the } \\
\text { short term around tree. } \\
\text { Reduce risk of tree becoming } \\
\text { waterlogged. }\end{array}$ & $\begin{array}{l}\text { Increases likelihood of soil } \\
\text { movement. }\end{array}$ \\
\hline
\end{tabular}




\subsection{Site Preparation on Peat Soils}

Development of plantations on peat swamp soils is different from development on mineral soil sites. Important guidelines for plantation development on peat are:

- A logging system should be employed which efficiently removes timber from the site leaving between 5 and 10 tonnes per hectare of residue. This allows planting without use of fire for site clearing;

- If commercial use of small size trees is not possible then logging followed by drainage, clearing and windrowing with a dozer mounted stick rake should be undertaken;

- Only the top 50-80 cm of the peat site should be drained to maintain the chemical and physical properties of the upper levels of peat;

- Where possible drains do not directly enter major watercourses (Class 1 or 2) but should drain to smaller streams (Class 3);

- Ripping is not recommended on peat sites;

- Fire must not be used in any site clearing or development operations; and

- Fire must be totally excluded from the site once plantation is established.

\subsection{Planting}

Planting will usually be done manually unless the area is established using seed applied by machine or the site is free of excessive residue and can be planted using a machine. The following guidelines apply to hand and machine planting.

- Planting stock (seedlings or cuttings) should be stored in a cool, moist location until planted.

- Planting spacing should be predetermined and closely adhered to. This may require some preliminary surveying.

- If soil has not been prepared by ripping, mounding or another technique, then a digging tool should be used to prepare the planting location.

- If containerised the planting stock should be carefully removed from its potting container avoiding root damage. 
- The planting stock should be placed into the soil with the roots pointing straight down to avoid "J" rooting (bent roots which reduce the trees health and increase its susceptibility to wind damage).

- Soil should be gently but firmly packed down around the root zone while tree is very gently lifted to straighten roots.

- Any plants not planted within 12 hours of being removed from the nursery should be placed in a cool, moist environment.

\section{Refilling/blanking}

If tree survival is not satisfactory (usually $<90 \%$ ), then refilling or blanking should be carried out. It is recommended:

- A survival survey is done within three weeks of planting; and

- Based on the results of the survey, refilling is done within one week of the survey.

\subsection{Herbicide and Pesticide Application}

Herbicide and pesticide application can not only enhance tree growth, but prevent tree death from competition and attack. However herbicides and pesticides can be dangerous to the planted tree crop, the environment and people within that environment if not carefully managed. It is recommended that an integrated pest and disease management system is developed for the plantation estate. The following guidelines are recommended:

- A census should be regularly carried out to determine pest and disease loads within the plantation;

- Applications must be based on research results and/or label/manufacturers recommendations;

- Herbicide/pesticide should only be applied on days when wind movement is very low;

- Workers must be provided with and wear appropriate safety equipment according to label recommendations; 
- Applications should be made during peak growing season on rain free days to maximise effectiveness and minimise movement offsite;

- Aerial applications should not be made close to community areas without consulting appropriate authorities and communities;

- Application of chemicals should be designed to minimise runoff and drift i.e. pellets are preferable to powder; and

- Surfactants should be used to maximise chemical effectiveness and minimise volume required. This also reduces costs.

\subsection{Fertiliser Application}

Fertiliser application often enhances tree growth. However, fertiliser runoff from plantations has negative effects on waterways and other species. Application must therefore be timely and directed to ensure the tree obtains the maximum benefit from the fertiliser. The following guidelines to achieve this are recommended:

- Applications should be based on research results or testing of the foliage nutrient content to ensure they are appropriate and effective;

- As much as possible fertiliser applications should be spread around the base of the tree and within the root zone;

- Applications should be made at a relatively dry time of the year to avoid runoff; and

- Application form should be designed to minimise runoff i.e. pellets are preferable to powder, or incorporated into the soil. 


\subsection{Alternatives to Herbicide/Pesticide/Fertiliser}

A range of alternatives to herbicides and pesticides (e.g. biological controls, genetically resistant trees) are now being developed which have the potential in many cases to lower costs and increase productivity. These should be investigated by growers and include:

- Use of cover crops to reduce weed competition and enhance nutrient levels on the site;

- Use of biological controls for tree pests and weeds;

- Maintenance of inter-row crops to reduce weed competition;

- Maintenance of exclusion zones to provide habitat for biological controls;

- Planting of more than one species or clone within a plantation to reduce pest loads or enhance biological control mechanisms;

- Selection of tree species and breeding for insect and pathogen resistance; and

- Specific site preparation techniques to enhance biological controls e.g. no fire.

Research into these techniques is continuing and will further decrease the reliance on herbicides and pesticides and fertilisers in the future. 


\section{Employee Conditions}

\section{OBJECTIVES}

- To provide a working environment which complies with or exceeds all national and international labour guidelines for wages, conditions and safety.

- To maximise the opportunity for local employment opportunities and skill base development.

\subsection{Working Conditions}

- The concessionaire should carry out an annual appraisal of human resources which identifies and is used to correct any deficiencies in staff capability and numbers.

- The concessionaire should endeavour to provide employment for local communities. This includes training to assist community members develop skills applicable to the plantation industry.

- An organisational structure should be developed, distributed throughout the company and explained to all staff members.

- A job description should be developed for all positions and explained to the relevant staff members.

- Appropriate training should be provided to staff to ensure they are capable of meeting the job description.

- Staff should be paid and work under conditions which meet or exceed those defined within the countries legislation and under the International Labour Organisation (ILO). This may include:

- wages;

- working hours;

- leave and compassionate leave;

- insurance; 
- superannuation/pension systems;

- equal opportunity in career development;

- gender equity;

- union participation;

- enterprise bargaining capacity;

- dispute resolution mechanisms;

- termination or redundancy; and

- safety equipment.

- Documentation must be developed detailing the concessionaire's policies and procedures for employment and professional development.

- A system should be provided for collating and investigating accident records. Reports on accidents should be analysed and the results of the analysis incorporated to operating procedures to minimise future accidents.

\subsection{Personnel Safety Requirements}

- A first aid kit in a suitable airtight and dust proof container should be provided and located close to harvesting crews and within each vehicle.

- Basic first aid training should be provided to all crew members of each working group according to ILO Code of Practice.

- All harvesting personnel to be provided with and wear:

- steel capped footwear; and

- high visibility jacket (red or orange colour).

- Chainsaw and harvesting operators are to be provided with and wear:

- safety helmet of International Standards Office (ISO) standard or equivalent;

- ear muffs/defenders which are capable of providing hearing protection for sound at over the 100 decibel level; and 
- leg protection made from cut-resistant materials (e.g. chainsaw chaps, leg piece).

- Workshop operators are to be provided with and wear:

- protective clothing, ear defenders, eye protection and gloves (when handling chemicals) as appropriate for the equipment being used (Table 11.1);

- respirators are required when painting and using industrial fluids.

\subsection{Equipment Safety Requirements}

- Safety requirements should comply with Part III of the ILO Code of Practice on Safety and Health in Forest Work.

- All chainsaws held directly by hand should have at least one of the following securely attached:

- rigid-type hand guard;

- functional chain brake;

- interlocking throttle.

- Chainsaw exhaust systems must direct the fumes away from the operator and conform with the chainsaw guidelines for the dry season operations.

- Chainsaw tool kit should be provided for corrective and preventative maintenance.

- Harvesting and roading equipment require:

- regular maintenance to achieve registered road worthy standards and a safety sticker;

- Roll Over Protection Structure (ROPS) and Falling Object Protection Structure (FOPS) cab or frame conforming to international standards securely mounted with high tensile nuts and bolts specified in fitting instructions;

- securely mounted seat and seat belt conforming to international standards;

- rear of cab or frame fitted with protective wire mesh; 
- reversing alarms on machines;

- securely guarded pulleys, shafts, belts and fan blades;

- positive, non-returning engine stopping device which is accessible from normal operating position and clearly marked with operating instructions;

- first aid kit;

- $\quad$ suitable fire extinguisher firmly fixed and easily retrievable; and

- $\quad$ exhaust system fitted with a spark arrestor at times of high fire risk.

All staff must be trained to follow safe working practices in the use and operation of all plant, equipment or substances they may handle or use. This includes wearing appropriate protective clothing as provided in Table 11.1. The following table provides a guide on protective clothing adapted from the ILO Code of Practice on Safety and Health in Forest Work provide sound guidelines on camp hygiene and should be consulted. 
Table 11.1 Guide to Protective Clothing

\begin{tabular}{|c|c|c|c|c|c|c|c|c|c|}
\hline $\begin{array}{l}\text { Part of body } \\
\text { to be } \\
\text { protected }\end{array}$ & Foot & Leg & $\begin{array}{l}\text { Trunk, } \\
\text { arms, } \\
\text { legs }\end{array}$ & Trunk & Hand & Head & Eye & $\begin{array}{l}\text { Eyel } \\
\text { Face }\end{array}$ & Hearing \\
\hline $\begin{array}{l}\text { Appropriate } \\
\text { Equipment }\end{array}$ & $\begin{array}{l}\text { Safety } \\
\text { boots or } \\
\text { shoes }\end{array}$ & $\begin{array}{l}\text { Safety } \\
\text { pants }\end{array}$ & $\begin{array}{l}\text { Close -fit } \\
\text { clothing }\end{array}$ & \begin{tabular}{|l|} 
High \\
visibility \\
clothing
\end{tabular} & Gloves & $\begin{array}{l}\text { Safety } \\
\text { helmet }\end{array}$ & Goggles & $\begin{array}{l}\text { Visor } \\
\text { (mesh) }\end{array}$ & $\begin{array}{l}\text { Ear } \\
\text { muffs }\end{array}$ \\
\hline Operation & & & & & & & & & \\
\hline Felling & & & & & & & & & \\
\hline Hand Tools & $\sqrt{ }$ & & $\sqrt{ }$ & $\sqrt{ }$ & $\sqrt{ }$ & $\sqrt{ }$ & & & \\
\hline Chainsaw & $\sqrt{ }$ & $\sqrt{ }$ & $\sqrt{ }$ & $\sqrt{ }$ & $\sqrt{ }$ & $\sqrt{ }$ & & $\sqrt{ }$ & $\sqrt{ }$ \\
\hline Mechanised & $\sqrt{ }$ & & $\sqrt{ }$ & $\sqrt{ }$ & & $\sqrt{ }$ & & & $\sqrt{ }$ \\
\hline Debarking & & & & & & & & & \\
\hline Manual & $\sqrt{ }$ & & & $\sqrt{ }$ & $\sqrt{ }$ & & & & \\
\hline Mechanised & $\sqrt{ }$ & & $\sqrt{ }$ & $\sqrt{ }$ & $\sqrt{ }$ & $\sqrt{ }$ & $\sqrt{ }$ & & $\sqrt{ }$ \\
\hline Extraction & & & & & & & & & \\
\hline Manual & $\sqrt{ }$ & & & $\sqrt{ }$ & $\sqrt{ }$ & $\sqrt{ }$ & $\sqrt{ }$ & & \\
\hline Chute & $\sqrt{ }$ & & & $\sqrt{ }$ & $\sqrt{ }$ & $\sqrt{ }$ & & & $\sqrt{ }$ \\
\hline Animal & $\sqrt{ }$ & & & $\sqrt{ }$ & $\sqrt{ }$ & $\sqrt{ }$ & & & \\
\hline Mechanised & & & & & & & & & \\
\hline Skidder & $\sqrt{ }$ & & $\sqrt{ }$ & $\sqrt{ }$ & $\sqrt{ }$ & $\sqrt{ }$ & & & $\sqrt{ }$ \\
\hline Forwarder & $\sqrt{ }$ & & $\sqrt{ }$ & $\sqrt{ }$ & $\sqrt{ }$ & $\sqrt{ }$ & & & $\sqrt{ }$ \\
\hline Cable crane & $\sqrt{ }$ & & $\sqrt{ }$ & $\sqrt{ }$ & $\sqrt{ }$ & $\sqrt{ }$ & & & $\sqrt{ }$ \\
\hline Helicopter & $\sqrt{ }$ & & $\sqrt{ }$ & $\sqrt{ }$ & $\sqrt{ }$ & $\sqrt{ }$ & $\sqrt{ }$ & & $\sqrt{ }$ \\
\hline $\begin{array}{l}\text { Stacking/ } \\
\text { loading }\end{array}$ & $\sqrt{ }$ & & $\sqrt{ }$ & $\sqrt{ }$ & $\sqrt{ }$ & $\sqrt{ }$ & & & $\sqrt{ }$ \\
\hline
\end{tabular}

Source: Adapted from ILO Code of Practice on Safety and Health in Forest Work 


\section{Fire Management}

\section{OBJECTIVES}

- To reduce incidence of forest fires through education and detection mechanisms.

- To protect plantations and other areas both within and outside the consession from fire.

Fire is regularly used in plantation development. While it can be a useful tool, it can also be used poorly and destroy the resource being developed, reduce productivity and destroy other resources in a region. Careful fire management is therefore essential.

\subsection{Education}

The best form of fire management is prevention. Humans cause most fires, so improving people's management of fire can significantly reduce the fire problem. Community education programs on fire risks and safe use of fire should be developed.

\subsection{Preparation}

To minimise fire risks a large plantation owner needs to be prepared for fire. A Fire Management Plan should be developed that includes detail of:

- Staff training in fire management and suppression;

- Development and maintenance of access tracks throughout the plantation to act as fire breaks and allow access should a fire occur;

- A planned system of fire breaks that may include roads, water bodies and areas burnt regularly to reduce fuel loads for the fire to burn;

- Techniques for locating fires within the concession such as fire lookout towers, aerial surveillance and community contact points; 
- Allocation and maintenance of resources for fire suppression such as water tankers, hand suppression equipment (mattocks, rakes etc) and heavy machinery (dozers and skidders with blades);

- A system for determining fire risk based on flammability of the concession and weather on a given day; and

- A mechanism for informing staff and the community in general of the fire risk and establish required levels of readiness dependant on fire risk.

In times of high fire risk, the following should be observed:

- All machine operations should cease if fire conditions are determined as "extreme";

- Machinery must be clear of surplus oil and accumulations of vegetative material around surfaces which will become heated;

- Refuelling should only be carried out where no flammable materials are within $3 \mathrm{~m}$ of the machine. This also applies to any welding activity;

- No fire may be left unattended in the forest;

- Fires for cooking or any other purposes shall only be lit when an area of 3 m radius has been cleared of flammable material around the fire;

- All fires must be completely extinguished before leaving a harvesting area;

- Training in regard to fire risk and control should be provided for workers; and

- Fire suppression equipment should be provided in areas of high fire risk.

\subsection{Fire Suppression}

If a fire is detected then immediate procedures should be put into place to extinguish the fire. These will require:

- Clear centralised management for the direction of resources;

- Accessible personal and machinery to attack the fire; and

- Clear communications within the field and to the fire management centre. 


\subsection{Chainsaws and Machines}

All chainsaws and machines should be fitted with functioning fire screen/spark arrestors prior to the fire season. 


\section{Harvesting Equipment Maintenance and Servicing}

\section{OBJECTIVES}

- To ensure machinery is sound and in safe working condition.

- To prevent pollution of water resources.

- To prevent introduction of non-endemic species and pathogens to new operating areas.

\subsection{Moving Equipment}

- All mechanical equipment (bulldozers, excavators, etc.) should to be washed thoroughly before it is moved to a new operational area to prevent the spread of weeds, pests and disease.

- Fuel or oil spillage is to be avoided during transportation.

\subsection{Workshop Facilities}

- Site at least $50 \mathrm{~m}$ from any water body or watercourse.

- Drainage from workshop areas should be diverted into collecting/settling ponds.

- Non-toxic solid waste should either be removed or buried and covered with at least $0.5 \mathrm{~m}$ of soil.

\subsection{Toxic Waste}

- The use of toxic substances is to be minimised and wherever possible biodegradable substitutes used. Toxic materials include spent hydraulic and refrigeration fluid, oil, fuel (petrol, diesel), workshop wastes, oily water, separator sludge and residues, industrial cleaners, paints and resins, preservatives (including timber treatment chemicals), distillates, lubricants, herbicides and pesticides. 
- Toxic materials are to be collected in containers securely sealed and preferably returned to municipal/township disposal areas, returned to the manufacturer or buried in an appropriate waste pit.

- Where onsite burial of toxic materials and their containers is the only alternative, the location of the pit should be clearly indicated (including signs in local languages), and the pit securely fenced.

- All waste pits are to be covered with at least $0.5 \mathrm{~m}$ of soil and located at least $100 \mathrm{~m}$ from maximum inundation by water and at least $1 \mathrm{~m}$ above maximum groundwater height.

\subsection{Main Fuel and Oil Storage}

- Locate main fuel and oil storage:

_ $\quad$ in a well drained area at least $50 \mathrm{~m}$ from any watercourse; and

- no closer than $100 \mathrm{~m}$ to village areas.

- Bunds (preferably concrete mounds) with a capacity of twice (x 2) the storage capacity must be provided around the storage.

- Drains are to be directed to a closed, stable and flood free disposal pit, at least $50 \mathrm{~m}$ from a watercourse or water body.

- Where main fuel storage must be located on a wharf, they should be:

- located as far away from the sea as the fuel pumping lines permit;

- fitted with a proper, leak-proof bund, which in the event of a spill is able to be pumped to a disposal pit at least $50 \mathrm{~m}$ from a water body. 


\subsection{Field Servicing and Maintenance}

- Field fuel tanks, refuelling points and maintenance areas are to be located:

- in well drained areas such as landings or road junctions;

- outside areas excluded from harvesting;

- more than $50 \mathrm{~m}$ from a watercourse.

- Prevent spillage during refuelling.

- Sump oil is not to be dumped in the harvesting areas. It should be collected and removed to the main disposal facility.

\subsection{Refuse Disposal}

- All solid waste should be placed in a refuse pit and buried. 


\section{Camp Hygiene}

\section{OBJECTIVES}

- To provide safe and healthy living conditions for camp personnel.

- To minimise pollution from camps.

The ILO Code of Practice on Safety and Health in Forest Work provide sound guidelines on camp hygiene and should be consulted.

\subsection{Camp Design Plans}

- Hygiene requirements should meet or exceed the ILO standards (ILO 1997; see standards for details).

- Detailed site plans are to include designs for sewage, water supply, waste water and waste disposal for new camp areas proposed for construction or expansion in that year.

\subsection{Water Supply}

- Camps must be supplied with potable water obtained from running streams, rainwater or wells.

- Water storage tanks should be properly screened to prevent the breeding of mosquitoes.

\subsection{Liquid Waste Disposal}

- Pit toilets should be located more than $100 \mathrm{~m}$ from water bodies used for drinking water supplies. 
- Sewage should be discharged so it does not enter:

- any stream; or

- the ocean at any point where it may cause a health risk to camp personnel or nearby communities.

- All drains are to be covered.

\subsection{Non Liquid Waste Disposal}

- Provide refuse disposal areas:

- in pits which are above the water table;

- where runoff water cannot enter;

- at least $50 \mathrm{~m}$ from any water body or watercourse.

- Cover refuse with soil to a depth of $30 \mathrm{~cm}$, at least once per week.

\subsection{Water Ponding}

Camp areas are to be well drained so that water does not pond and create mosquito breeding areas.

\subsection{Additional Facilities}

Additional facilities in camps should include:

- medical;

- educational;

- recreational; and

- spiritual, where appropriate. 


\section{Competency Based Training System for Plantations}

\section{OBJECTIVES}

- To ensure that all staff engaged in forest planning, harvest planning, harvesting operations and plantation establishment are competent in the use and maintenance of equipment and to carry out the assigned tasks.

- To ensure that staff responsible for particular tasks understands the requirements of those tasks.

Competency based training ensures that all operators are capable of meeting the minimum skills required to fulfil their job description. Properly trained staff with the necessary competencies for undertaking forest harvesting and associated activities work more safely and effectively leading to more efficient work practices with less downtime due to injury and machinery breakdowns.

For effective Code implementation it will be essential to develop and introduce a competency based training system. To develop minimum competency standards, skill level and training needs assessment should be carried out intiallly.

\subsection{Minimum Competency Standards}

It is desirable that minimum competency standards be developed for each of the following vocations:

- Plantation supervisors;

- Plantation planners/surveyors;

- Machine operators; 
- Tree fellers;

- Log measurers;

- Animal handlers, truck drivers, railway operators, helicopter pilots, skyline operators, boat and barge operators; and

- Safety officers.

It is suggested that the following competencies are essential.

\section{Competencies for planning and survey}

- Understanding of the Codes and its requirement for:

- watercourse class recognition and buffer zones;

- road location, alignment and construction;

- skid track location, alignment and construction; and

- navigation techniques and equipment (compass and GPS).

- Aerial photography and interpretation.

- Road design and survey.

- Watercourse crossing location and construction.

- Correct marking and recording of survey information.

- Community/Stakeholder consultation.

\section{Competencies for equipment operation and maintenance}

- Certification of skills and competencies from a recognised training institution for equipment operators (for chainsaws, boats, harvesting and transport machines).

- Specific competencies in safe work practices as indicated in ILO Code of Practice on Safety and Health in Forest Work.

- Understanding by staff of the requirements of the Code and their individual tasks. 


\section{Competencies for harvesting and associated procedures}

- All staff engaged in harvesting and associated procedures are competent to meet the needs of their position, including:

- determining accurate log length and diameter measurement and assessing defect allowance;

- tree and log marking requirements.

- Certification of all log measurers.

- Harvesting monitoring and post-harvest evaluation. 


\section{GLOSSARY}

$\begin{array}{ll}\text { abutment } & \text { End support for bridge, culvert or similar structure. } \\ \text { adverse grade } & \text { Grade up which a loaded log truck must travel. } \\ \text { back-cut } & \text { The final cut involved in felling a tree. The back-cut } \\ \text { should be higher than the scarf. } & \text { Inclination or shape of side slope of walls, banks, } \\ \text { cuttings. } & \text { Heap of soil associated with the side of a road or skid } \\ \text { batter } & \text { track. } \\ \text { berm } & \text { See refilling } \\ \text { blanking } & \text { The range of species of plants and animals in an } \\ \text { biodiversity } & \text { ecosystem. } \\ \text { borrow pit } & \text { An excavation outside the limits of road construction } \\ & \text { for obtaining fill used for roadway construction. } \\ \text { box-cut } & \text { An area created through a ridge where there is no } \\ & \text { possibility of drainage and there is earth on both sides } \\ & \text { of the road. } \\ & \text { Area of vegetation retained around a sensitive area or } \\ \text { site. Harvesting and disturbance is excluded from these } & \text { areas. } \\ \text { buffer area } & \text { The stump end of a log. } \\ \text { cadastral } & \text { A ridge of wood that develops in the angle between a } \\ \text { lateral root and the base of a stem to provide lateral } \\ \text { root stability to the stem. } \\ \text { Any haul system using a machine with powered drums, } \\ \text { suttress }\end{array}$




\begin{tabular}{|c|c|}
\hline camber & The amount of crossfall on a road around curves. \\
\hline catch drain & $\begin{array}{l}\text { A drain constructed above a batter to prevent erosion } \\
\text { of the batter by surface water. }\end{array}$ \\
\hline catchment & The area which yields run-off water to a given point. \\
\hline chain brake & $\begin{array}{l}\text { A safety device on a chainsaw designed to stop the } \\
\text { chain in the event of a kickback. }\end{array}$ \\
\hline chaps & $\begin{array}{l}\text { Chainsaw chaps are safety trousers which are cut } \\
\text { resistant and contain material designed to protect } \\
\text { against chain saw cuts. }\end{array}$ \\
\hline chopper rolling & $\begin{array}{l}\text { Use of a large circular drum with metal blades which is } \\
\text { dragged behind a machine to break up material left on } \\
\text { site after harvesting is completed. }\end{array}$ \\
\hline clearfelling & Felling and removal, of all standing commercial timber. \\
\hline competency & $\begin{array}{l}\text { A standard that must be achieved by an individual to } \\
\text { show they are capable of carrying out that activity in } \\
\text { the workplace. }\end{array}$ \\
\hline contour & $\begin{array}{l}\text { An area of the same height running around a slope. } \\
\text { This should be followed when contour mounding, } \\
\text { ripping, wind rowing, etc. }\end{array}$ \\
\hline cording & $\begin{array}{l}\text { Laying of suitable logs, bark or vegetation on the soil } \\
\text { to separate machine tyres or tracks from direct soil } \\
\text { contact. }\end{array}$ \\
\hline cross-cut & Cutting through a felled log. Also called bucking. \\
\hline cross-drain & $\begin{array}{l}\text { Drain constructed across a track to divert water to a } \\
\text { stable disposal area. }\end{array}$ \\
\hline cross fall & $\begin{array}{l}\text { To shape a landing, road or track so that it is higher in } \\
\text { the centre than the outside, allowing water to drain to } \\
\text { the sides. }\end{array}$ \\
\hline cultural area & $\begin{array}{l}\text { Area of social, cultural, historical or anthropological } \\
\text { importance to indigenous populations. Includes } \\
\text { villages, gardens and sites which are culturally } \\
\text { sensitive. }\end{array}$ \\
\hline
\end{tabular}


culvert

designated watercourses

directional felling

drilling

end haul

endangered

environmental sensitivity

exclusion zone

felling jack

firebreak

flute, fluting

forest officer
A channel or conduit carrying water across or under a road. Usually a pipe running under the road from the higher side to the lower side.

Those required to be marked on plans. They include all classes of streams and gullies where vegetation buffers are to be marked and retained.

Felling a tree in a particular direction.

Inserting a vertical cut into the stem with a chainsaw to determine the presence of internal defect. Defect is indicated by discoloured sawdust or soft wood.

Excavation and removal of spoil to another site. End haul is used where side casting of material is not appropriate.

Flora and fauna species in danger of extinction.

Classification of the importance of a particular area of land or forest to degradation.

Any area which is excluded from harvesting. Includes conservation areas, cultural areas, habitat areas, greenbelts and buffers

Tool inserted into the backcut during felling to provide leverage to force the tree to fall in a particular direction.

Any barrier to a fire. May include water bodies, roads, deliberately constructed mineral earth areas and burnt areas.

Supporting buttresses at the base of some species. Employee of the forest agency or other agency authorised, under the relevant legislation, to administer one or more of the forest regulations. 


\begin{tabular}{|c|c|}
\hline formation width & The width of a road, excluding batters. \\
\hline forum & $\begin{array}{l}\text { A committee made up of representatives from the } \\
\text { concessionaire and the community with the power to } \\
\text { make decisions and tasked with ensuring that } \\
\text { stakeholder issues and needs are addressed. }\end{array}$ \\
\hline geographic information system (GIS) & $\begin{array}{l}\text { A computerised mapping system and database which } \\
\text { uses layers to store information which can be retrieved } \\
\text { and at the scale required. }\end{array}$ \\
\hline geotextile & $\begin{array}{l}\text { A material sheet placed on road surfaces to assist in } \\
\text { drainage and road stabilisation. }\end{array}$ \\
\hline guard log & $\begin{array}{l}\text { Log along the outside of bridge, above the main stringer } \\
\text { logs to prevent gravel from falling from the bridge into } \\
\text { a watercourse. }\end{array}$ \\
\hline gully & $\begin{array}{l}\text { Gullies are steep-sided channels. The slope of at least } \\
\text { one bank exceeds } 15^{\circ} \text {. Depth of the bank adjacent to } \\
\text { the bed may be } 30 \mathrm{~cm} \text { or more. Vegetation may be } \\
\text { growing in the gully bed. Water will flow for less than } \\
2 \text { months in most years. }\end{array}$ \\
\hline habitat & $\begin{array}{l}\text { Area or tree (habitat tree) used by fauna for food and } \\
\text { dwellings. }\end{array}$ \\
\hline harvesting contract & $\begin{array}{l}\text { Legal agreement negotiated between landowners (State, } \\
\text { private or customary) and harvesting companies for the } \\
\text { harvesting of forests. }\end{array}$ \\
\hline harvesting debris & $\begin{array}{l}\text { Broken logs, branches, vines or other tree material } \\
\text { created as a result of felling and skidding. }\end{array}$ \\
\hline harvesting supervisor & $\begin{array}{l}\text { Concessionaires supervisor responsible for the } \\
\text { management of harvesting operations in the field. }\end{array}$ \\
\hline head wall & A retaining wall at the inlet end of a culvert. \\
\hline hinge wood & $\begin{array}{l}\text { The quantity of wood remaining between the scarf and } \\
\text { back-cut during tree felling }\end{array}$ \\
\hline
\end{tabular}




hung-up tree
integral arch
landing
landscape level plan
log cluster
log pond
log scaling
main road
plantation
management information system
mound ploughing
out-slope

A tree which has not completely reached the ground following cutting.

An extension to the winch of a harvesting tractor which gives lift to one end of the $\log$.

Area where logs are extracted to after harvesting and prior to being transported.

A long term plan which provides broad description and details of future harvesting and development activity across the entire concession area.

Group of 3 or more logs placed in a triangular fashion to act as a culvert.

Main storage area for logs awaiting shipment or processing.

Measurement of logs for the purpose of determining volume.

A permanent road capable of carrying large volumes of timber.

A computerised system involving GIS used for the record keeping and management of a forest enterprise. Use of a plough to create a raised mound into which trees can be planted

Retaining wall placed at the outlet end of a culvert. Sloping the surface of a track to shed water to the downhill side.

Concessionaires employees responsible for planning. A forest crop or stand raised artificially by sowing seed or planting seedlings or clones raised in a nursery. Water dammed by poor roading or site development. Results in loss of productive area. Replacement of trees which have died in the first round of plantation establishment. Also called blanking. 


\begin{tabular}{|c|c|}
\hline ripping & $\begin{array}{l}\text { Use of a ripping tyne which is dragged through the } \\
\text { soil by a large machine to break the soil up and reduce } \\
\text { compaction allowing better tree root and water access. }\end{array}$ \\
\hline rotation & $\begin{array}{l}\text { The planned number of years between the } \\
\text { establishment of a crop of trees and the time when the } \\
\text { same crop is felled for final harvest. }\end{array}$ \\
\hline saddle & A low point on a ridge or spur. \\
\hline scarf & $\begin{array}{l}\text { Two cuts made when directional felling to remove a } \\
\text { wedge of wood and direct the trees direction of fall. }\end{array}$ \\
\hline sediment trap & See silt trap. \\
\hline shoreline & Limit of high tide; limit of mangrove growth. \\
\hline shoulder & See verge. \\
\hline side cast & $\begin{array}{l}\text { Pushing material to the side, usually during road or } \\
\text { track construction. }\end{array}$ \\
\hline side drain & Drain which diverts water from a table drain. \\
\hline sight distance & $\begin{array}{l}\text { The distance along a road or track that a driver can } \\
\text { see other objects (usually other vehicles). }\end{array}$ \\
\hline silt trap & $\begin{array}{l}\text { Hole dug to catch sediment in run-off water flowing in } \\
\text { drains. Log or rock bars may also be used. }\end{array}$ \\
\hline skid track & Track along which a log is pulled by a tractor. \\
\hline skidding & The pulling of logs from the felling point to a landing. \\
\hline skyline yarding system & $\begin{array}{l}\text { A cable yarding system which makes use of a heavy } \\
\text { wire rope ( the skyline) which is stretched between two } \\
\text { spars (or spar trees) and used as a track for a skyline } \\
\text { carriage. The system enables the log to be fully } \\
\text { suspended during extraction. }\end{array}$ \\
\hline stakeholders & $\begin{array}{l}\text { Individuals or groups of individuals who have an } \\
\text { interest in, or an impact on, the outcomes of a } \\
\text { decision as well as groups or individuals dependent } \\
\text { to some degree on the outcome for their personal or } \\
\text { institutional goals. }\end{array}$ \\
\hline
\end{tabular}


stand

stand level plan

stick rake

stream

superannuation

sustainable forest management
A single contiguous age class planting of the same species and commonly referred to as stands, compartments, blocks or management units. Generally size is less than one hundred hectares. Forms the base management unit for plantation management.

Plan providing precise details of harvesting activities for the stand, including location of roads, landings and skid tracks.

A blade for a dozer/skidder or excavator bucket made up from a series of steel prongs like a fork.

This allows earth and fine material to pass through the rake while larger material is caught and can be moved. Stream is a watercourse where water may flow for more than 2 months in most years. The beds are generally characterised by the presence of clean, water-washed stone, gravel, or exposed bedrock materials.

Class 1 stream: width of the stream base $=$ more than $20 \mathrm{~m}$ Class 2 stream: width of the stream base $=10$ to $20 \mathrm{~m}$ Class 3 stream: width of the stream base $=$ less than $10 \mathrm{~m}$. Money put aside by the company and or the employee for the employees benefit when they cease working for the company.

The process of managing permanent forest land to achieve one or more clearly specified objectives of management with regard to the production of a continuous flow of desired forest products and services without undue reduction in its inherent values and future productivity and without undue undesirable effects on the physical and social environment (Definition of the International Tropical Timber Organisation). 


swamp
table drain
temporary crossing
tree crown
understorey
v-drain
verge

village
water bar
watercourse

wedge

winch rope

windrow

wing wall
Surface water present for 6 months of the year. The drain parallel to and at the side of a road. A watercourse crossing which will be removed after harvesting.

Leaves and branches which make up the top of the tree. That part of the forest vegetation growing below the forest canopy.

"V"-shaped table drain.

The part of the road construction continuous and flush with the pavement on either side. It is generally only used by passing vehicles but may be used for travel by track machines.

A cluster of dwellings in a rural environment.

\section{See cross-drain.}

Defined line that receives and conducts concentrated overland flow for some period in most years. Flows may be permanent or periodic. Watercourse includes a stream, and a gully. Classes are defined in terms of permanency of flow, bed material, bed width and side slope.

A high impact plastic or aluminium wedge driven into the back-cut to assist directional felling. Flexible wire rope used to winch logs towards the skidding tractor.

Pushing/heaping of vegetation into rows to allow access across the site for planting and other operations. Side walls provided at a culvert or bridge to retain road fill material. 


\section{References}

ABARE - Jaako Pöyry. 1999. Global Outlook for Plantations. Australian Bureau of Agricultural and Resource Economics. ABARE, Canberra.

Asia-Pacific Forestry Commission 2000. Regional Strategy for Implementing the Code of Practice for Forest Harvesting in Asia-Pacific. CIFOR, Bogor, Indonesia.

Food and Agriculture Organization (FAO) 1989. Wathershed management field manual: Road design and construction in sensitive watersheds. Guide FAO: Conservation 13/5. FAO, Rome.

International Labour Organization (ILO). 1997. Code of Practice on Safety and Health in Forest Work: Meeting of Experts on Safety and Health in Forest Work. ILO, Geneva.

Additional relevant International Organisation for Standardisation (ISO) Standards not presented in the ILO Code of Practice on Safety and Health in Forest Work are as follows:

No.

ISO 11161

ISO 13860

ISO 13861

ISO 13862

ISO 6531

\section{Title}

Industrial automation systems - Safety of integrated manufacturing systems - basic requirements 1994. Machinery for forestry - Forwarders - terminology and specifications (Draft) 1997.

Machinery for forestry - Wheeled skidders Terminology and specifications (Draft) 1997. Machinery for forestry - Feller bunchers - Terminology and specifications (Draft) 1997.

Machinery for forestry - Portable chain saws Vocabulary 1982. 


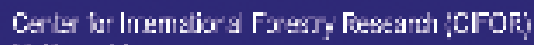

Maiing adf res:

PÖ. Eox t5:6 JTPWE.

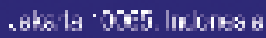

CHes a:dmaz: .a an CIFOR,

Sild Eeta, Sir cora Bara ih,

Ecasr Barat 16606; I-dovegis

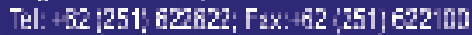

E-ral dits gevjor.og

Wabsita: htt::twawidarogisers?
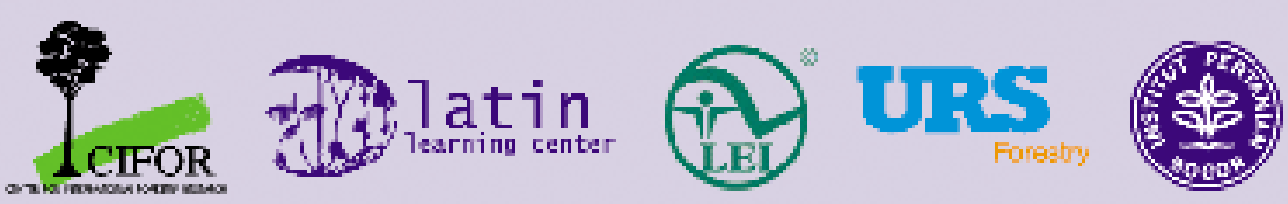

APRIL 